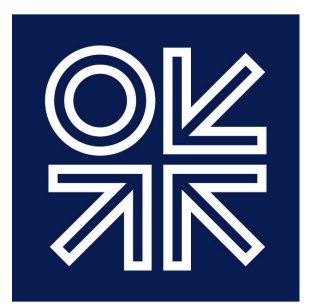

THE OXFORD

INSTITUTE

FOR ENERGY

STUDIES

\title{
Issues in the pricing of domestic and internationally-traded gas in MENA and sub-Saharan Africa
}

\section{Hakim Darbouche*}

\author{
NG 64
}

June 2012

*I am grateful to Jonathan Stern, Mostefa Ouki, Howard Rogers and John Elkins for their useful comments on an earlier draft. Any mistakes, in fact or interpretation, remain my own. 
The contents of this paper are the authors' sole responsibility. They do not necessarily represent the views of the Oxford Institute for Energy Studies or any of its members.

Copyright $\mathbb{C} 2012$

\section{Oxford Institute for Energy Studies}

(Registered Charity, No. 286084)

This publication may be reproduced in part for educational or non-profit purposes without special permission from the copyright holder, provided acknowledgment of the source is made. No use of this publication may be made for resale or for any other commercial purpose whatsoever without prior permission in writing from the Oxford Institute for Energy Studies.

ISBN

$978-1-907555-53-4$ 


\section{Preface}

In an age where future international natural gas trade is assumed to continue to accelerate and the countries of the Middle East and Africa are assumed to play a substantial role in providing the necessary export volumes, this paper by Hakim Darbouche serves as a timely reminder that proved reserves statistics do not necessarily translate smoothly into export flows.

Whilst it is evident that the countries of the Middle East and North Africa (MENA) and subSaharan Africa hold almost $50 \%$ of the world's proven reserves, with much additional potential for the discovery of more conventional and unconventional resources, a deeper understanding of the political economy of these gas resource-rich countries is necessary in order to realistically appraise their future participation in the global natural gas system.

Continuing his excellent analysis of the gas markets of Algeria and Egypt in chapters of the OIES book 'Natural Gas Markets in the Middle East and North Africa', published in 2011, Hakim assesses the role of natural gas in the MENA and sub-Saharan Africa. Whilst it is unwise and difficult to generalise across such a wide swath of geography, certain themes recur. These include the historic perception of gas having a low inherent value as a byproduct of oil production, the use of low-priced gas as a currency for perpetuating the 'social compact' between regimes and the subject population, the challenges faced when domestic demand overtakes domestic production availability and the increasing pressures on state finances as the need for high priced imports, or the consumption of oil in the domestic power sector, are accepted as seductive but expensive short term expedients.

The necessity for gas price reform of what are effective ill-targeted subsidy systems, intentional or otherwise, looms larger with the passage of time though in the aftermath of the Arab Spring, the ability to implement such changes can understandably be difficult for regional leaders. Nevertheless such measures are being attempted, with varying success. In Nigeria this has been met with resistance but, as Hakim describes with justification, in Iran the process has been relatively well managed and appears to be bearing fruit in terms of improved efficiency of gas utilisation and a more progressive targeting of subsidy to poorer households.

Clearly, if the region is to play a greater role in global natural gas trade than at present the issues of pricing reform and resource governance in general, although politically difficult, need to be addressed. This paper offers an objective appraisal of the challenges faced and an unrivalled understanding of the country-specific dynamics by an expert in the subject.

Howard V Rogers 


\section{Contents}

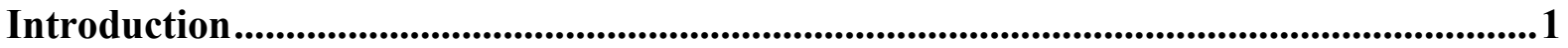

PART ONE: The political economy of domestic gas pricing ............................................4

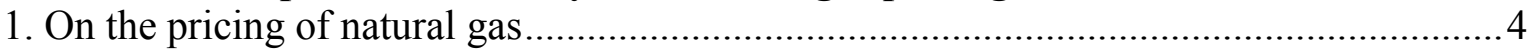

Domestic gas prices in MENA and sub-Saharan Africa ............................................ 5

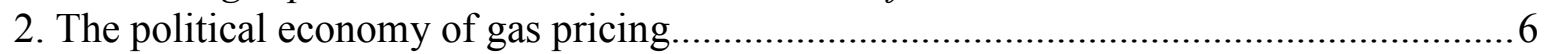

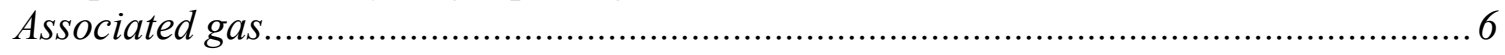

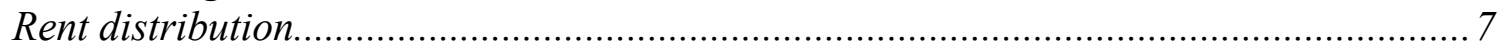

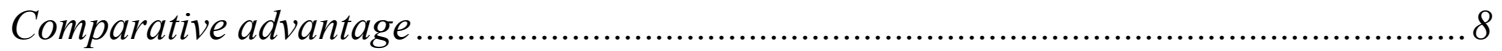

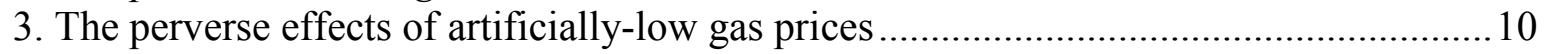

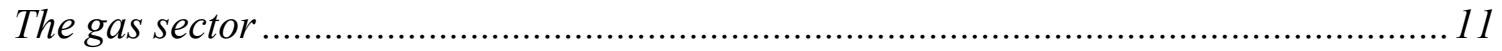

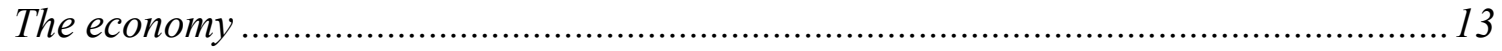

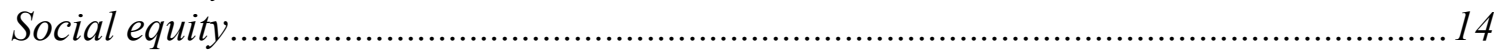

4. Revising gas pricing policies: Lessons from the Iranian experiment ........................... 15

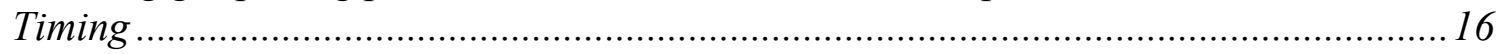

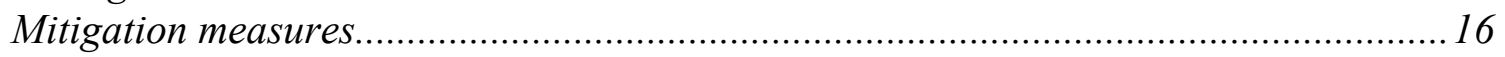

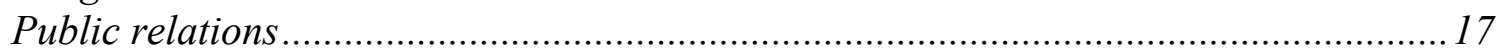

PART TWO: The pricing of internationally-traded gas.................................................17

5. The pricing of internationally traded gas in MENA and sub-Saharan Africa ................. 17

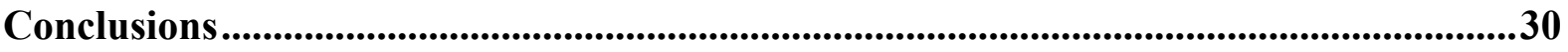

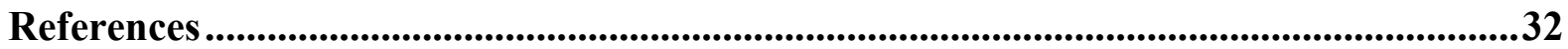

\section{Tables}

Table 1: MENA and sub-Saharan Africa gas data, 2000-2010 ............................................. 1

Table 2: Share of hydrocarbons in selected MENA and sub-Saharan Africa economies (data for 2010).

Table 3: Ethylene production capacity in MENA vs. other regions, 2001-2011 (thousand tons

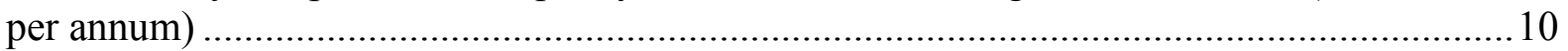

Table 4: Energy subsidies data in selected countries (data for 2010) ..................................... 14

Table 5: Sonatrach's gas supply contracts (as at May 2012) .............................................. 19

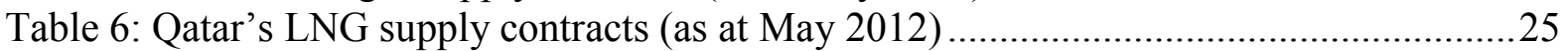

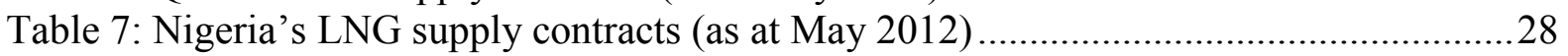

\section{Figures}

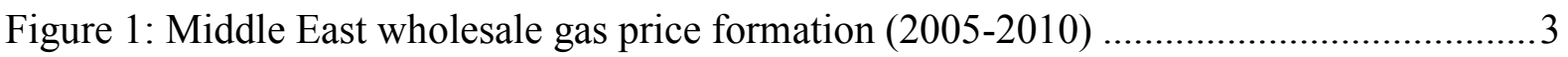

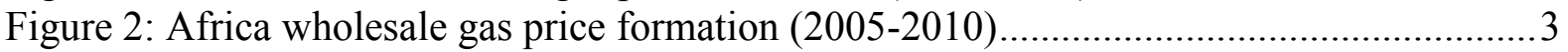




\section{Introduction}

The countries of the Middle East and North Africa (MENA) and sub-Saharan Africa hold more than 90 trillion cubic of meters $(\mathrm{Tcm})$ of gas reserves, or almost $50 \%$ of the world's proven reserves, with much additional potential for the discovery of more conventional and unconventional resources (namely tight/shale gas and coal-bed methane). However, their contribution to total world gas trade - both pipeline and LNG - in 2010 amounted to no more than $25 \%$, with only a few MENA and sub-Saharan Africa countries importing gas from outside both regions and only in marginal volumes. Despite the fact that both regions' current share of international gas trade represents a net increase, primarily in exports, of almost $10 \%$ compared to 2000 , more than $70 \%$ of gas output is consumed in-country and within these regions (Table 1$)$.

Demand for natural gas in these regions grew by almost $90 \%$ between 2000 and 2010, driven overwhelmingly by countries in MENA. In many of these countries, demand has been growing faster than supply, leading to gas shortages, export restrictions, and even imports of gas. In sub-Saharan Africa, energy poverty, including in the countries with large hydrocarbon resources, remains a major issue, with only a third of households having access to electricity and modern energy services. In terms of gas, even in the countries with the larger reserves, such as Nigeria, Angola, Equatorial Guinea and Cameroon, domestic markets suffer from inadequate supply and infrastructure.

Table 1: MENA and sub-Saharan Africa gas data, 2000-2010

\begin{tabular}{|c|c|c|c|c|c|c|c|c|c|}
\hline \multirow{2}{*}{} & \multicolumn{2}{|c}{ Production (Bcm) } & \multicolumn{3}{c|}{ Consumption (Bcm) } & \multicolumn{2}{c|}{ Share of int'l trade (\%) } \\
\cline { 2 - 11 } & MENA & $S S A$ & Total & $M E N A$ & $S S A$ & Total & $M E N A$ & $S S A$ & Total \\
\hline 2000 & 346 & 17 & $\mathbf{3 6 3}$ & 238 & 11 & $\mathbf{2 4 9}$ & 14.5 & 0.9 & $\mathbf{1 5 . 4}$ \\
\hline 2001 & 362.4 & 19.6 & $\mathbf{3 8 2}$ & 263 & 12 & $\mathbf{2 7 5}$ & 16.1 & 1.4 & $\mathbf{1 7 . 5}$ \\
\hline 2002 & 379 & 18 & $\mathbf{3 9 7}$ & 276 & 10.6 & $\mathbf{2 8 6 . 6}$ & 16 & 1.3 & $\mathbf{1 7 . 3}$ \\
\hline 2003 & 407 & 24 & $\mathbf{4 3 1}$ & 289 & 12 & $\mathbf{3 0 1}$ & 16.1 & 1.9 & $\mathbf{1 8}$ \\
\hline 2004 & 445 & 30 & $\mathbf{4 7 5}$ & 313 & 17 & $\mathbf{3 3 0}$ & 15.9 & 1.9 & $\mathbf{1 7 . 8}$ \\
\hline 2005 & 483 & 30.5 & $\mathbf{5 1 4}$ & 348 & 18.5 & $\mathbf{3 6 6 . 5}$ & 17.6 & 1.7 & $\mathbf{1 9 . 3}$ \\
\hline 2006 & 514.2 & 36.8 & $\mathbf{5 5 1}$ & 362 & 19 & $\mathbf{3 8 1}$ & 19.2 & 2.4 & $\mathbf{2 1 . 6}$ \\
\hline 2007 & 540.6 & 43.6 & $\mathbf{5 8 4}$ & 377 & 20 & $\mathbf{3 9 7}$ & 19.4 & 2.9 & $\mathbf{2 2 . 3}$ \\
\hline 2008 & 570 & 46 & $\mathbf{6 1 6}$ & 412 & 22 & $\mathbf{4 3 4}$ & 20.6 & 3.4 & $\mathbf{2 4}$ \\
\hline 2009 & 571 & 44 & $\mathbf{6 1 5}$ & 428 & 23 & $\mathbf{4 4 3}$ & 19.8 & 2.8 & $\mathbf{2 2 . 6}$ \\
\hline 2010 & 622 & 51.5 & $\mathbf{6 7 3 . 7}$ & 448 & 25 & $\mathbf{4 7 3}$ & 21.4 & 3.3 & $\mathbf{2 4 . 7}$ \\
\hline
\end{tabular}

Sources: BP and Cedigaz 
Notwithstanding the political, economic and social differences between MENA and subSaharan Africa, both regions are grouped here for the purpose of understanding domestic pricing policies in gas-rich developing countries, which is one of the objectives of this paper. To a significant extent, underlying MENA's fast demand growth and sub-Saharan Africa's underdeveloped gas markets is the general tendency of government energy policies to keep end-user gas prices at artificially-low levels, even if in the latter region issues of economic structures, gas sector organisation and institutional capacity have been at least as (if not more) constraining for gas market development as pricing policies. Domestic prices for gas in most countries in these regions are well below opportunity values, and indeed below the marginal cost of new supply in some instances. Therefore, it comes as no surprise that gas markets in these regions suffer from numerous distortions as a result of systemic government intervention (Figures $1 \& 2$ ). The resulting status quo has become untenable in the majority of countries in these regions, yet pricing reforms remain tentative, if at all.

Generally, justifications for energy subsidies vary from social welfare protection, job creation, the promotion of new sources of energy supply and economic development to energy security. In the particular case of gas in MENA and sub-Saharan Africa, government pricing policies tend to be rooted in three main - and often interrelated - political economy logics, which this paper will explore. First, gas was often initially produced in associated form (from oil production) and considered a free by-product of oil ${ }^{1}{ }^{1}$ second, gas resources are seen as a source of rent that can be distributed by unaccountable governments as part of the social contract they articulate to maintain the political status quo; and third, the availability of abundant gas (and other energy) resources encourages the formulation of economic development paradigms that advocate the leveraging of these resources as a source of competitive advantage for industrial development and economic diversification. However, it remains uncertain whether subsidies serve their intended purpose and whether current pricing logics are reflective of the new supply/demand realities in gas markets in these regions.

Besides reviewing the issue of domestic gas prices in these regions, its origins, effects and potential remedies, this paper will examine the pricing of internationally-traded gas in MENA and sub-Saharan Africa, describing the mechanisms underpinning the main pipeline and LNG supply contracts in these regions. It is organised in two parts. The first deals with issues of political economy relating to domestic gas pricing, and is divided into five sections. The first section introduces some basic concepts of gas pricing and costs. The second section provides details of current gas prices in MENA and sub-Saharan Africa. The third section analyses the political economy of gas pricing in these regions. The fourth section examines the adverse effects of gas subsidies. And the final section attempts to draw policy lessons from the Iranian subsidy reform programme. The second part examines the pricing of international traded gas in MENA and sub-Saharan Africa. It describes the pricing mechanisms in the main export and import contracts in these regions, helping assess the disconnect between domestic prices and international prices and its implications for gas use in these regions.

\footnotetext{
${ }^{1}$ Typically, early hydrocarbon exploration focussed on oil prospects in preference to gas given the relative ease of transporting oil to market.
} 
Figure 1: Middle East wholesale gas price formation (2005-2010)

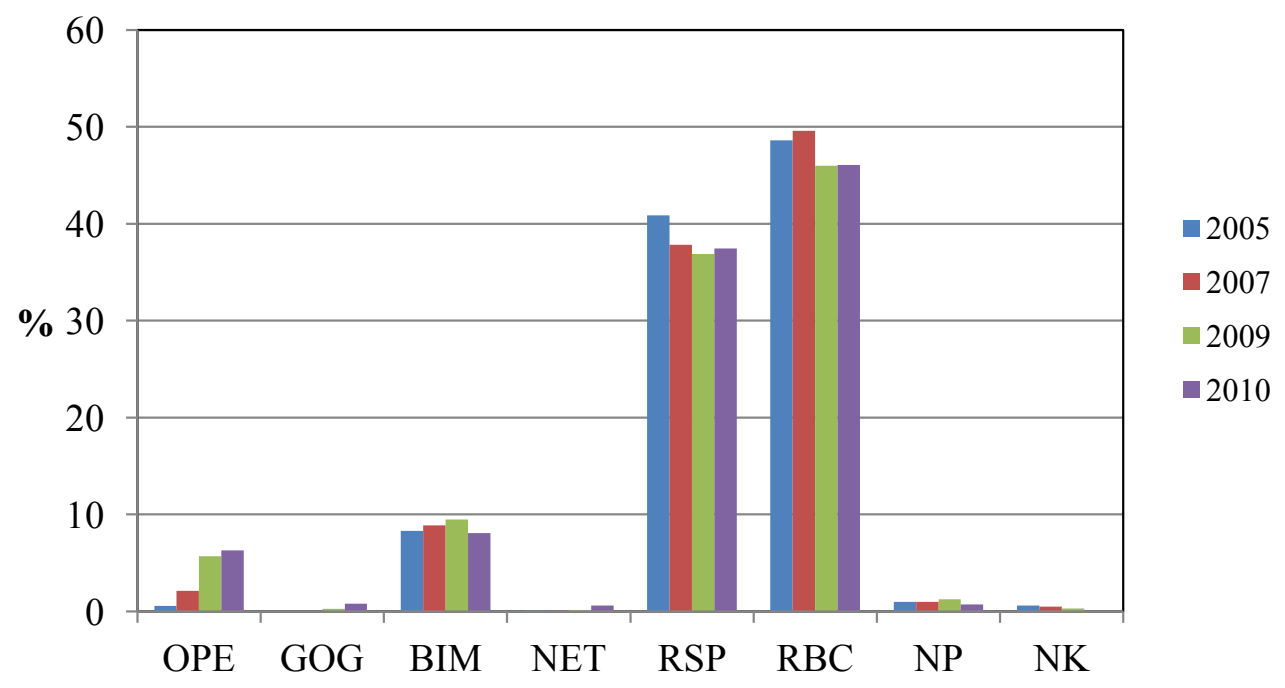

Figure 2: Africa wholesale gas price formation (2005-2010)

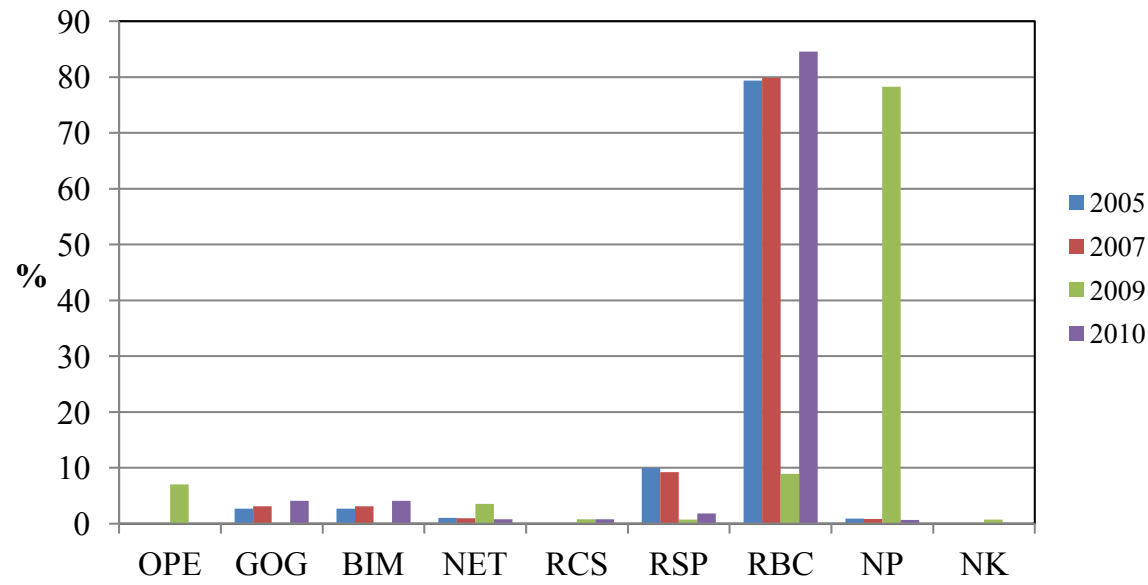

Source: International Gas Union - IGU (2012)

Note: Types of gas price formation

OPE: Oil Price Escalation

GOG: Gas-on-Gas

BIM: Bilateral Monopoly

NET: Netback From Final Product

RCS: Regulation (Cost of Service)

RSP: Regulation (Social and Political)

RBC: Regulation (Below Cost)

NP: No Price

NK: Not Known 


\section{PART ONE: The political economy of domestic gas pricing}

\section{On the pricing of natural gas}

The pricing of energy in general for domestic consumers is often complex and controversial, and natural gas is no exception. The importance of gas as a fuel and feedstock for various economic sectors and the complexity of gas project value chains mean that there is a multitude of considerations that come into play when defining pricing policies. Julius and Mashayekhi (1990: 116) identified three sets of objectives upon which government domestic pricing policies are generally predicated: the efficiency of resource allocation; the satisfaction of specific financial targets; and considerations of social equity. While prices need to reflect the real opportunity value of gas development for an economy so as to send the right signals to consumers and producers, they have to ensure both the financial viability of utilities and a fair redistribution of resources to the poorest segments of society. In similar vein, in a report published in 2001, the World Energy Council points to "the three As" as being the main objectives of government pricing policies, namely accessibility, availability and acceptability. $^{2}$

Thus, between offering the right incentives for exploration and production (E\&P) risk-takers, capturing some of the resource rent, encouraging large consumers to shift to gas, and protecting small consumers from monopoly exploitation by utilities, governments in developing gas-rich countries are often faced with a difficult balancing act. Contrary to developed countries where the challenge in terms of pricing policies and market reform is often to bring prices down to the competitive cost of service, for developing countries it is more a question of setting prices high enough to cover the cost of delivering the service and ensuring adequate payment collection, while at the same time protecting vulnerable industrial and household consumers from the inflationary effect of higher prices.

Central to the debate about gas pricing and subsidies more generally is the issue of cost. Without a proper estimation of costs, adequate pricing and accurate measurement of subsidies would remain elusive. However, there are several economic concepts of cost and generally no agreement between economists on the one hand and policy-makers in different countries on the other as to what constitutes the most appropriate basis for gas pricing.

Among the concepts most commonly referred to in the literature are average cost, marginal cost and opportunity cost. ${ }^{3}$ The first refers to the overall cost per unit of output and is measured by the sum of both investment and direct costs. Marginal cost is the increment in total cost resulting from a unit change in output. Finally, opportunity cost is unrelated to production costs and refers to the foregone value of the resource when that resource is not utilised in its best alternative use. ${ }^{4}$

For internationally-traded commodities such as natural gas, the consensus among economists is that the appropriate reference price corresponds to the international price, adjusted for transportation and internal distribution costs (i.e. import or export parity). In other words, for a country that can export gas, the true value of production at the margin corresponds to what

\footnotetext{
2 'Pricing energy in developing countries', The World Energy Council, London, available at: http://www.regulationbodyofknowledge.org/documents/163.pdf.

${ }^{3}$ See World Energy Council (2001); IEA/OPEC/OECD/World Bank (2010), 'Analysis of the scope of energy subsidies and suggestions for the G-20 Initiative', 16 June, Available at: http://www.oecd.org/dataoecd/55/5/45575666.pdf

${ }^{4}$ For more details, see Luciani, G. (forthcoming - 2012) 'Domestic pricing of energy and industrial competitiveness', in: G. Luciani, (ed.) Resource Blessed: Diversification and the Gulf Development Model, Berlin: Gerlach.
} 
it could obtain on the international market (the best alternative use). As such, if the country can produce at a cost that is lower than the international price, domestic production should be valued at international prices rather than at domestic supply costs. Similarly, for an importing country, the true cost of gas should be the import price.

In fact, even when the gas is not actually traded, it can be assigned a value based on fuel switching if it is able to physically substitute for crude oil and oil products, typically in the power generation sector. On this basis, the international price of oil or oil products can, at least under certain conditions and with the right adjustments for power generation efficiency and transport costs, provide a reference price for non-traded gas in the domestic use market. In simple terms, a unit of domestically produced gas saves an equivalent unit of imported fuel or releases a unit of fuel for export, which means that the unit value of the imported/exported fuel (converted and adjusted for the purposes of correct reference) is the gross opportunity value of gas.

However, in countries with large hydrocarbon resources, the use of the opportunity cost measure is not as straightforward as it may seem, as recognised by the report on subsidies published in 2010 by the IEA, OPEC, OECD and the World Bank. ${ }^{5}$ If the domestic gas requirement exceeds the amount of gas produced in association with oil and natural gas liquids (NGLs), and thus at the margin is no longer able to be considered "a free by-product", then development of the required additional gas production capacity to satisfy growing domestic demand incurs its own investment costs. As a result, the most relevant concept would be marginal cost plus, depending on the size of the reserve base, a depletion premium. The latter is an additional amount equivalent to the present value of the opportunity cost of extracting the resource at some time in the future, over and above its economic price today. ${ }^{6}$

\section{Domestic gas prices in MENA and sub-Saharan Africa}

By and large, gas prices in the main gas producing countries in MENA and sub-Saharan Africa are well below both international prices and the cost of new domestic gas supply (marginal cost). They vary from \$0.75/MMBtu in Saudi Arabia, \$0.8/MMBtu in Kuwait, \$1/MMBtu in Qatar and the UAE to about \$0.6/MMBtu in Algeria and \$1.25-3/MMBtu in Egypt. In sub-Saharan Africa, Nigeria is currently the only country with a significant gas market (12 Bcm/yr), with gas prices in the range $\$ 0.1-0.3 / \mathrm{MMBtu}$, going up more recently to some \$1/MMBtu. South Africa has a much smaller gas market (3-4 Bcm/yr), but its gas pricing mechanism is the closest to a market-based approach in these two regions. It is based on alternative fuel indexation and volume-based categorisation, and includes a floor (cost of delivery for Sasol) and a ceiling (European Benchmark Price based on a basket of prices at six West European gas trading hubs). This applies to the Mozambican gas that Sasol develops and ships to South Africa under a 25 -year contract. ${ }^{7}$

Most of these countries are facing gas shortages of some sort, owing in the majority of cases to growing gas demand, fuelled largely by the artificially-low prices, and their inability to bring new gas supply to market under the prevailing pricing and other commercial conditions. Gas pricing issues have received a great deal of attention in policy circles in recent years, especially where this is constraining the development of new production or diverting supplies which would otherwise have been exported, but very few governments have taken decisive action to address them.

\footnotetext{
${ }^{5}$ IEA/OPEC/OECD/World Bank (2010), p. 14.

${ }^{6}$ For a detailed analysis of the concept in the MENA context, see: Razavi, H. (2009) 'Natural Gas Pricing in Countries of the Middle East and North Africa', The Energy Journal, 30 (3), pp. 1-22.

${ }^{7}$ For more details, see "The agreement concerning the Mozambican gas pipeline between the government of the Republic of South Africa and Sasol Limited" that can be accessed here: http://www.nersa.org.za.
} 
Iran appears to be the exception. It is the only country that has so far moved in the direction of phasing out gas and energy subsidies more generally. Beginning in December 2010, the implementation of a five-year subsidy removal programme will see gas prices rise from as low as $\$ 0.15 / \mathrm{MMBtu}$ for the power sector for instance up to $65-75 \%$ of the average Iranian gas export price, or some $\$ 6-8 / \mathrm{MMBtu}$ at $\$ 100 /$ barrel crude oil prices. ${ }^{8}$ Egypt and Bahrain appear to have made more modest attempts at revising their domestic gas prices, with the former raising the price of gas for energy-intensive users to $\$ 3 / \mathrm{MMBtu}$ and the latter raising gas prices by $50 \%$ to $\$ 2.25 / \mathrm{MMBtu}$ in January 2012 , in anticipation of becoming an importer of LNG in coming years. Nigeria is notionally in the process of introducing new petroleum legislation, through the Petroleum Industry Bill (PIB), and a Gas Master Plan, the aim of which is partly to revise gas prices upwards and introduce more market-oriented pricing mechanisms, but fierce opposition to the proposed reform from industrial and political stakeholders has so far delayed its implementation.

The events of 2011 that have come to be described as the "Arab Spring" have accentuated governments' longstanding reluctance to tackle the issue of domestic energy pricing. ${ }^{9}$ But the fact that supply shortages are turning into fiscal, energy security and environmental crises in many of these countries should mean that, sooner or later, we will see prices revised upwards to allow new gas supply to be brought to market, based on the price required to explore for and develop new discoveries. The apparent success of the ongoing Iranian energy subsidy reform experiment - in the sense that the government was able to introduce and maintain its course on radical pricing reform which appears to be having an impact on demand rationalisation - will undoubtedly provide useful benchmarks for the rest of the MENA region and beyond, though it is important to bear in mind that pricing reforms will always hinge on country-specific political, social and economic circumstances.

\section{The political economy of gas pricing}

In most countries in MENA and sub-Saharan Africa, gas development policies - including gas pricing - cannot be considered in isolation from other aspects of energy policy and, more importantly, from the political economy of governments' developmental policies. This is because in a number of cases gas is (at least initially) produced in association with oil and NGLs and thus regarded as a free by-product of the more-valued liquid hydrocarbons. It is also perceived as a way of rent distribution by the state for the poorer segments of the population. And thirdly low gas prices are seen as a source of comparative advantage for expansion into higher value-added industries and economic diversification. These are the three most common political economy logics underpinning gas pricing policies in gas-rich countries in MENA and sub-Saharan Africa.

\section{Associated gas}

In a number of MENA countries, particularly the Gulf Cooperation Council (GCC) countries (except Qatar and Oman), and the gas-rich countries in sub-Saharan Africa (Nigeria, Angola and Equatorial Guinea), the biggest share of gas production comes from associated gas. Only relatively recently have some of these countries begun exploring for and developing nonassociated gas reserves to meet their growing domestic requirements. Saudi Arabia has turned its attention to offshore gas development, bringing on stream in 2011 the Karan nonassociated gas field, the first of a string of other fields, having failed in its earlier - though

\footnotetext{
${ }^{8}$ The Iranian gas price index $(\mathrm{P})$ is calculated using the following formula: $\mathrm{P}=0.118 \times \mathrm{JCC}-0.215$. The author is grateful to David Jalilvand for sharing this information.

${ }^{9}$ For more details, see: Darbouche, H. and Fattouh, B. (2011) 'The Implications of the Arab Uprisings for Oil and Gas Markets', MEP 2, OIES, available at: http://www.oxfordenergy.org/wpcms/wpcontent/uploads/2011/09/MEP_2.pdf.
} 
still ongoing - attempt to transform the Empty Quarter into a gas-producing province (Fattouh, 2011). Similarly, Kuwait and the UAE have shifted their upstream efforts towards tight, "sour" and offshore gas reserves, but with uncertain results so far because of the technical and commercial complexity of many of these projects. By comparison, Libya began developing its non-associated gas reserves earlier, bringing online in 2004 the West Libya Gas Project and embarking (at least prior to the 2011 revolution) on an ambitious offshore exploration campaign, aiming mostly to expand its export capacity, both pipeline gas and LNG. ${ }^{10}$

With oil being the main and most-valued output on which production is scaled, gas was viewed in many of these countries, at least in the earlier days of their hydrocarbon sector development, as at best a by-product and at worst a nuisance. As a result, associated gas was flared in large quantities, and although great strides have been made in the last 30 years to reduce the level of flaring, an estimated $70 \mathrm{Bcm} / \mathrm{yr}$ of gas is still flared in both the MENA and sub-Saharan African regions, or the equivalent of almost $50 \%$ of the current global gas flaring level. ${ }^{11}$ However, towards the late 1970 s and early 1980 s, many countries, particularly in the MENA region, began processing some of the associated gas and putting it to use as feedstock for newly created industries and later on as fuel for power generation. Some countries, such as Abu Dhabi and Libya and more recently Nigeria, Equatorial Guinea and Angola, have used associated gas as feedstock for LNG production and exports.

Accordingly, prices of gas, which was essentially considered a free by-product, were fixed at very low levels. At most, what was factored into these prices was the cost of the infrastructure required to capture, process and deliver the associated gas to end-users. As oil production across these regions continued to expand throughout the last 30 years and domestic gas demand growth remained relatively manageable, the pricing policies pursued in many of these countries appeared justified, or at least were faced with far fewer challenges than today. However, as the reinjection requirements of mature oil (and wet gas) fields increased and domestic demand from the power and industrial sectors boomed, many countries, particularly in the MENA region, needed additional gas supply, but their existing pricing policies acted as impediments to the development of new (and usually nonassociated) gas reserves. In sub-Saharan Africa, particularly in Nigeria, the situation is more serious, in the sense that a combination of low gas prices, complex sector organisation and institutional inefficiency meant that the domestic gas market has remained largely underdeveloped, even as hard currency proceeds from LNG exports started flowing from 1999.

\section{Rent distribution}

In the majority of cases, by the time it becomes necessary to revise existing gas prices they will have become deeply entrenched in the "social compact" that ties state and society in many of these countries, with many vested interests developing around the existing system. This means that even if there was willingness on the part of governments to revise their policies and increase prices, they would likely face fierce resistance from various social, industrial and political stakeholders. However, in actual fact many governments in these regions have themselves a political interest in providing highly visible services, such as gas and power, at low cost. Although the majority of these governments do not face elections, they do confront other existential tests. In particular, they fear socio-political instability of the sort seen in 2011 across the Arab world. This is what Victor (2009) calls the "populist paradox" - subsidies being often provided by governments that do not face popular referenda.

\footnotetext{
${ }^{10}$ African Energy (2010), 'Libya's Energy Future', London: Cross-border Information.

${ }^{11}$ Farina, M.F. (2011) 'Flare Gas Reduction: Recent Global Trends and Policy Considerations', GE Energy, available at: http://www.genewscenter.com/ImageLibrary/DownloadMedia.ashx?MediaDetailsID=3691.
} 
Thus, for governments, administered prices are considered a rent distribution mechanism. They voluntarily relinquish the potential rent they would receive from gas exports or higher domestic prices, in favour of public and private-owned industries (in an effort to create jobs) and households (in order to protect their income). Of course, as we will see below, such pricing practices are far from being the most effective mechanism of rent distribution, as they tend to encourage rent-seeking behaviour in the targeted industries and to benefit the rich at the expense of the poor. However, besides lacking the political will and/or the ability to take on vested interests, governments in these countries often lack the administrative capacity to devise an alternative delivery mechanism that is better suited to their goals and the needs of the end-users they purportedly seek to support.

\section{Comparative advantage}

Most of the gas-rich countries in the MENA and sub-Saharan Africa regions exhibit an overwhelming economic dependence on the hydrocarbons sector (Table 2). Such dependence has created numerous structural economic vulnerabilities and deficiencies in these countries, stemming essentially from their exposure to the vagaries of international oil markets and their rent-based political economy. This is the reason why economic diversification has been the main pillar and a constant feature of governments' development policies since the 1970s. And for many of these governments, the leveraging of locally available raw materials such as oil and natural gas for industrial diversification purposes appeared, and still is considered, the most obvious choice to make. Algeria for instance, one of the first countries in these regions to have a dedicated gas development strategy, aimed from the 1970s through the 'valorisation of its natural gas resources to create the foundation for the state's financial independence [away from hydrocarbons]'. ${ }^{12}$ Similarly, Saudi Arabia and other GCC countries have turned to gas as the fuel of choice for their industrialisation strategies, which are largely based on the development of energy-intensive industries such as petrochemicals, steel, aluminium and fertilisers. ${ }^{13}$

\footnotetext{
${ }^{12}$ Aïssaoui, A. (2001) Algeria: The Political Economy of Oil and Gas', Oxford: OIES/OUP.

${ }^{13}$ For more details, see: Aïssaoui, A. (forthcoming) 'Saudi Arabia's Economic Diversification: Progress in the Context of the GCC and Challenges'; Economist Intelligence Unit (2010) 'The GCC in 2020: Broadening the Economy', available at: http://graphics.eiu.com/upload/eb/AVIVA \%20GCC to 2020 Economic diversification in GCC WEB.pdf 
Table 2: Share of hydrocarbons in selected MENA and sub-Saharan Africa economies (data for 2010)

\begin{tabular}{|c|c|c|c|}
\hline & \% of GDP & \% of exports & \% of fiscal receipts \\
\hline Algeria & 35 & 98 & 86 \\
\hline Libya & 65 & 85 & 85 \\
\hline Saudi Arabia & 40 & 35 & 75.9 \\
\hline UAE & 31.5 & 92 & 49 \\
\hline Qatar & 51.7 & 68.9 & 76 \\
\hline Oman & 46.5 & 72 & 75 \\
\hline Iran & 10.5 & 97 & 75.9 \\
\hline Nigeria & $20-40$ & 97.6 & 71.3 \\
\hline Angola & 46 & 98.8 & \\
\hline Equatorial Guinea & 53.6 & & \\
\hline
\end{tabular}

Source: IMF

For MENA countries in particular, this strategy meant that they have become major players on global petrochemical markets, rivalling major producers in Asia, Europe and the Americas (Table 3), but the effectiveness of vertical integration along the energy value chain and expansion into higher value-added products for economic diversification tends to be disputed. Yet, for governments in gas-rich developing countries, the availability of cheap energy, coupled with the general absence of other resources, particularly high-end skills and knowhow, represents a potential competitive advantage that is almost the only way readily available to attract the necessary investment and achieve enunciated developmental goals. Thus, gas pricing policies are seen as a tool to provide the necessary incentives for investment in specific industries - something that governments in developed countries achieve by other means. However, as gas shortages have become more acute in countries such Algeria, Egypt, Oman, Nigeria and even Saudi Arabia, governments are considering taking, or have taken action towards increasing gas prices for energy-intensive industries, especially those that are export-oriented. 
Table 3: Ethylene production capacity in MENA vs. other regions, 2001-2011 (thousand tons per annum)

\begin{tabular}{|c|c|c|c|c|}
\hline & 2001 & 2006 & 2011 & Process \\
\hline Algeria & 120 & 120 & 120 & Steam cracker - ethane \\
\hline Egypt & 300 & 300 & 300 & $\begin{array}{l}\text { Steam cracker - } \\
\text { ethane/propane }\end{array}$ \\
\hline Iran & 694 & 1,602 & 5,293 & $\begin{array}{l}\text { Steam cracker - } \\
\text { ethane/propane }\end{array}$ \\
\hline Iraq & 85 & 132 & 132 & Steam cracker - ethane \\
\hline Israel & 200 & 200 & 300 & Steam cracker - naphtha \\
\hline Kuwait & 800 & 800 & 1,650 & Steam cracker - ethane \\
\hline Libya & 330 & 330 & 19 & Steam cracker - naphtha \\
\hline Qatar & 525 & 1,025 & 2,520 & Steam cracker - ethane \\
\hline Saudi Arabia & 5,870 & 7,140 & 13,075 & $\begin{array}{l}\text { Steam cracker - } \\
\text { ethane/propane }\end{array}$ \\
\hline UAE & 28 & 600 & 2,100 & Steam cracker - ethane \\
\hline MENA & 8,950 & 12,250 & 25,510 & \\
\hline Americas & 37,700 & 39,900 & 38,950 & \\
\hline Europe & 24,420 & 27,120 & 26,710 & \\
\hline FSU & 3,700 & 3,880 & 4,210 & \\
\hline Asia Pacific & 28,830 & 36,330 & 50,340 & \\
\hline
\end{tabular}

Source: Nexant Inc. (2012)

\section{The perverse effects of artificially-low gas prices}

In spite of being rooted in a logic that is specific to gas-rich developing countries, policies of artificially-low gas prices are not without adverse consequences for the gas sector, the economy as a whole and for social equity in these countries. In essence, their outcome is often dislocated from governments' own objectives and indeed from the objectives that ought to guide governments' pricing policies as outlined above. For a start, low prices result in distorted consumption patterns, inducing greater demand for gas than would otherwise result if consumers paid the (higher) opportunity price. They also produce a bias in terms of investment in favour of gas export infrastructure at the expense of the domestic market, in cases where exports of gas are allowed. They can affect government fiscal and trade balances, especially in countries with relatively limited fiscal headroom and resource endowments, and even the long-run growth potential of an economy. And, as is well known, universal subsidies are not the most efficient means of redistributing income, or improving access to energy for the poor. 


\section{The gas sector}

It is well established that subsidies or artificially-low prices stimulate consumption patterns that do not correspond to the structure of relative scarcities. ${ }^{14}$ Gas consumption particularly in the MENA region almost doubled between the years 2000 and 2010, growing from around $240 \mathrm{Bcm} / \mathrm{yr}$ to just under $450 \mathrm{Bcm} / \mathrm{yr}$, making it among the fastest-growing and the third highest gas-intensive region in the world after the former Soviet Union countries and North America, with a per capita consumption rate of some 1,200 cubic meters. This growth is highly concentrated in the Gulf countries, including Iran, as well as in Egypt. Although low prices are not the only factor stimulating demand growth in MENA, with rapid population and urban growth, strong demand for power and the drive for economic diversification being other important factors, they are in many cases a key driver of gas consumption.

Furthermore, the absence of clear price signals raises the issue of whether the current allocation of gas between various sectors, such as petrochemicals versus power generation and exports versus domestic use, is efficient and maximises the value of what is becoming a scarce resource in many of these countries. ${ }^{15}$ This is becoming particularly pertinent considering that, on the supply side, low prices are no longer suited to cover the cost of new supply, domestic or imported, that the majority of countries will need to develop in order to meet their future domestic requirements. This is because, in many cases, consumer subsidies undermine supply availability, with the price paid to producers and the transmission tariffs, leading to adverse outcomes for gas project development.

In sub-Saharan Africa, the effect of low prices on gas market development has been particularly severe, owing to the added constraints generated by the unfavourable wider political, institutional and social development conditions. This is most notably the case in Nigeria, sub-Saharan Africa's biggest gas reserve-holder, producer and consumer. Thus, in a region of some 800 million people, gas consumption stood at only $30 \mathrm{Bcm}$ in 2010 , which is almost equivalent to the amount of gas flared throughout the region. With the coming online in 2012 of Angola's first (5.2 mtpa) LNG train, it is estimated that a third of sub-Saharan African gas will be exported, a third consumed locally, and the rest flared.

Aside from Nigeria, only South Africa, Ivory Coast, Equatorial Guinea and Tanzania have domestic gas markets, albeit relatively small. South Africa sits on a resource base of conventional gas estimated at less than 1 Tcf, but it is believed to have a much larger unconventional gas potential, particularly in terms of coal-bed methane (CBM) and shale gas. Its annual consumption is less than $4 \mathrm{Bcm}$, most of which is in the industrial sector as more than $90 \%$ of South Africa's power generation capacity is coal-fired. Production from the Mossel Bay gas fields, currently estimated at around $2 \mathrm{Bcm} / \mathrm{yr}$, has been feeding PetroSA's GTL plant, though declining fairly rapidly in recent years. And since 2004, following the commissioning of the $865-\mathrm{km}$ pipeline linking Mozambique's onshore Temane and Pande gas fields to Sasol's synthetic fuels and chemical plants at Secunda, South Africa has been importing 3-3.5 Bcm/yr. ${ }^{16}$

\footnotetext{
${ }^{14}$ Bressand, F. et. al. (2007) 'Curbing Global Energy Demand Growth: The Energy Productivity Opportunity', McKinsey Global Institute, available at:

http://www.mckinsey.com/Insights/MGI/Research/Natural_Resources/Curbing_global_energy_demand_growth ; Hang, L. and Tu, M. (2007) 'The Impact of Energy Prices on Energy Intensity: Evidence from China', Energy Policy, 35 (5), pp. 2978-2988.

${ }^{15}$ A scarce resource not necessarily in terms of gas that could be developed at prices equivalent to those being paid for imports, but rather the more limited volumes that could be developed at the prevailing (low) domestic price.

${ }^{16}$ Favreau, D. (2010) ‘A Review of Natural Gas Markets: South Africa’, Cedigaz Insights No. 8, June.
} 
The Ivory Coast consumes between $1.5-2 \mathrm{Bcm} / \mathrm{yr}$ and does not import or export any gas. All of its gas supply comes from offshore fields, some of which are associated, and is used mainly in power generation. Gas is delivered by field operators Foxtrot, Canadian Natural Resources and Afren to public and independent power generators under long-term contracts with take-or-pay provisions and prices indexed to oil products. In 2010, gas supply prices varied between $\$ 4$ and $\$ 8 / \mathrm{MMBtu} .^{17}$

Equatorial Guinea produces mostly associated gas from the Alba and Zafiro fields offshore Bioko Island. In 2010, its output is estimated to have reached almost $7 \mathrm{Bcm}$, the bulk of which was exported as LNG. Only about $1.5 \mathrm{Bcm} / \mathrm{yr}$ are consumed locally, mostly to feed a methanol plant and small power plant near the Punta Europa facility on Bioko Island. As for Tanzania, it has been consuming less than $1 \mathrm{Bcm} / \mathrm{yr}$ from its offshore Songo Songo field since it came on stream in 2004, using the gas mostly for power generation, but also for the industry and transport sectors. Songo Songo, the first and so far only offshore commercial producing field in East Africa, contains an estimated $50 \mathrm{Bcm}$ of proven gas reserves and its production capacity is expected to increase to $1.5 \mathrm{Bcm} / \mathrm{yr}$ by the end of 2012 to satisfy Tanzania's growing demand. However, with East Africa's gas exploration boom since 2010, and the discovery by early 2012 of an estimated $2.8 \mathrm{Tcm}$ of gas offshore Mozambique and Tanzania alone, there will be more than enough gas in East Africa to satisfy demand in local and regional markets and to develop LNG exports.

Limited gas supply and infrastructure are among the main reasons behind sub-Saharan Africa's acute power crisis. Total installed power generation capacity across the region was estimated at 68,000 MW in 2010, or less than the capacity available in Spain. Most of that capacity $(40,000 \mathrm{MW})$ is in South Africa, which means that the rest of the region has a power generation capacity equivalent to the installed capacity in Argentina alone. Unsurprisingly therefore, less than a third of the region's population has access to electricity, with access in rural areas falling to as low as $10 \%$. As a result, $70 \%$ of the population rely on wood (and its by-products) as primary cooking fuel. ${ }^{18}$

Nigeria, which is the most populous country in sub-Saharan Africa with an estimated 170 million people, epitomises this crisis. Only half of its 8,000 MW installed power generation capacity is available because of gas supply shortages, poor plant maintenance and transmission/distribution deficiencies. This means that less than $40 \%$ of the population has access to electricity, with the rest either relying mostly on diesel-fired independent generators or on solid fuels. ${ }^{19}$ To remedy this situation, the government devised a yet-to-be-fullyimplemented Gas Master Plan in 2008, the aim of which is to set a new framework for the development of the domestic gas sector. The envisaged reforms include a domestic supply obligation (DSO) for upstream operators, pricing reforms, and a blueprint for infrastructure development.

\footnotetext{
${ }^{17}$ Autorité nationale de Régulation du Secteur de l'Electricité :

http://www.anare.ci/espace_operateur_prive/fournisseur_gaz.asp

${ }^{18}$ For detailed analyses of energy poverty in sub-Saharan Africa, see: Legros, G. et al. (2009) 'The Energy Access Situation in Developing Countries: A Review Focusing on the Least Developed Countries and subSaharan Africa', WHO/UNDP, available at: http:/content.undp.org/go/cmsservice/stream/asset/?asset_id=2205620; World Bank (2009) 'Africa Energy Poverty', paper prepared for the G8 Energy Ministers Meetings, Rome 24-25 May 2009, available at: http://www.g8energy2009.it/pdf/27.05/G8_Africa_Energy_Poverty_May9_Final_JS_clean.pdf. ${ }^{19}$ Tallapragada, P.V.S.N. (2009) 'Nigeria's Electricity Sector: Electricity and Gas Pricing Barriers', International Association for Energy Economics, available at: www.iaee.org/en/publications/newsletterdl.aspx?id=72
} 
The DSO measure stipulates that the Nigerian National Petroleum Corporation (NNPC) should obtain from upstream partners a minimum share of gas reserves and output for domestic use, without which penalties would be imposed and no exports of gas allowed. Price reforms introduce a 3-tier pricing system, grouping end-users into a strategic domestic sector, a strategic industrial sector and a commercial sector. Prices for the strategic domestic sector (essentially power generation) will be set on a cost of supply basis; for the strategic industrial sector (where gas is used as feedstock) on a product netback basis whereby the price of gas is a function of the price of the output produced by the buyer; and for the commercial sector (where gas is used as fuel) on an alternative fuels basis. Finally, the Gas Master Plan aims to revamp Nigeria's gas transport and transmission infrastructure, expanding the existing Escravos-Lagos Pipeline System, linking it to the gas reserves in the eastern part of the country, and linking the southern networks to the north of the country where there is very little gas penetration. ${ }^{20}$

\section{The economy}

Generally, gas subsidies are only a small part of the larger energy subsidy expenditure that governments in the MENA and sub-Saharan Africa regions sustain (Table 4). Nevertheless, they contribute to the distortion effects on the economy associated with subsidies, affecting government accounts by leading to a worsened fiscal balance through net current transfers. This often comes at the expense of government spending in other areas of social policy, such as health and education, especially in countries with over-burdened fiscal balances. In Egypt for instance, a country with a fiscal deficit of more than $8 \%$ in 2010-11, expenditure on energy subsidies of around $\$ 16$ billion in the fiscal year 2011-12 exceeded total spending on the health ( $\$ 4$ billion) and education ( $\$ 9$ billion) sectors combined.

All things being equal, energy subsidies are also likely to affect the balance of payments as they lead to increased domestic demand for imported, or potentially exportable, energy products, thus worsening the trade balance. They can also affect the long-run growth potential of an economy by deterring innovation, technological development and productivity growth, and affecting individuals' decisions in the allocation of factors of production and distribution of consumption over time. They affect relative prices and investment decisions by companies and may have significant adverse effects on the allocation of resources across sectors and economic agents due to these price signals not affecting overall social costs of ${\text { energy } \text { use. }^{21}}^{21}$

\footnotetext{
${ }^{20}$ For more details on Nigeria's Gas Master Plan, see: Onyeukwu, H. (2009) 'Nigerian Gas Master Plan and Policy: Is it a Constrained Energy Policy?’, available at: http://works.bepress.com/humphrey onyeukwu/6

${ }^{21}$ World Bank (2010) 'Subsidies in the Energy Sector: An Overview', Background paper for the World Bank Group energy sector strategy, available at: http://siteresources.worldbank.org/EXTESC/Resources/Subsidy background paper.pdf.
} 
Table 4: Energy subsidies data in selected countries (data for 2010)

\begin{tabular}{|l|c|c|c|c|}
\hline & $\begin{array}{c}\text { Total energy } \\
\text { subsidies } \mathbf{( \$ ~ b n ) ~}\end{array}$ & $\begin{array}{c}\text { Share of gas } \\
\mathbf{( \% )}\end{array}$ & $\begin{array}{c}\text { Total subsidies } \\
\text { as \% of GDP }\end{array}$ & $\begin{array}{c}\text { Fiscal balance } \\
\text { as \% of GDP }\end{array}$ \\
\hline Algeria & 10.6 & -- & 6.6 & -1.1 \\
\hline Libya & 4.2 & 6.2 & 5.7 & 8.7 \\
\hline Egypt & 20.3 & 11.8 & 9.3 & -8.1 \\
\hline Saudi Arabia & 43.5 & -- & 9.8 & 6.7 \\
\hline Qatar & 4.2 & 34 & 3.2 & 2.9 \\
\hline UAE & 18.2 & 54.9 & 6 & -1.1 \\
\hline Iraq & 11.3 & 2.5 & 13.8 & -9.1 \\
\hline Kuwait & 7.6 & 11.8 & 5.8 & 22.6 \\
\hline Iran & 80.8 & 31.6 & 22.6 & -8.5 \\
\hline Nigeria & 2.9 & -- & 1.3 & 7.7 \\
\hline Angola & 1.1 & -- & 1.3 & \\
\hline
\end{tabular}

Sources: IEA and IMF

NB: The IEA calculates energy subsidies using the price-gap approach (more details are available here http://www.worldenergyoutlook.org/methodology sub.asp). Its data is used in this table to provide an indication of the size of gas (and energy) subsidies and may not correspond to figures quoted in other sections of this paper, which are largely derived from national government sources. The apparent absence of subsidies for gas in Algeria, Saudi Arabia, Nigeria and Angola is the result of the fact that these countries have relatively large gas reserves and that the IEA considers that domestic gas prices in these countries cover the cost of production.

\section{Social equity}

Although energy subsidies are often formulated with the aim of providing low-income households with energy at affordable prices, there is plenty of economic evidence that suggests that universal subsidies have an inherent pro-rich bias. ${ }^{22}$ The poorest segments of the population may not be able to afford even subsidised energy or may have no physical access to it, as is the case in Nigeria where only less than $40 \%$ of the population have access to electricity, most of whom are based in the urban centres. Even if the poor are able to benefit from subsidies, the benefits accruing to them may be relatively small given that their consumption levels are generally modest. This was the case in Iran for example, where it is estimated that the three top income groups captured more than $40 \%$ of the gas subsidies compared to less than $20 \%$ for the three lowest income groups. ${ }^{23}$ However, despite their regressive nature, suddenly removing energy subsidies can have adverse effects on the poor in the short term, especially in countries that lack adequate mechanisms for protecting the most vulnerable from the resulting higher prices.

\footnotetext{
${ }^{22}$ See: Coady, D. et al. (2010) 'Petroleum Product Subsidies: Costly, Inequitable, and Rising', IMF Staff Position Note, February, available at: http://www.imf.org/external/pubs/ft/spn/2010/spn1005.pdf; UNEP (2002) 'Reforming Energy Subsidies: Opportunities to Contribute to the Climate Change Agenda', available at: http://www.unep.org/pdf/pressreleases/reforming_energy subsidies.pdf.

${ }^{23}$ Salehi-Isfahani, D. (2010) 'Will Iran's Poor Lose from Subsidy Reform?', available at: http://djavad.wordpress.com/2010/03/15/will-irans-poor-lose-from-the-subsidy-reform.
} 


\section{Revising gas pricing policies: Lessons from the Iranian experiment}

The problem with energy subsidies is that, once established, they become difficult to reduce or remove, especially when provided on a universal basis. With time they become entrenched in political economy practices to the extent that consumers perceive energy prices as a highly politicised issue under the control of governments, resisting any attempt to remove them. As a result, despite the fiscal burden they inflict on most governments and their adverse effects on long-term economic development and efficient resource allocation, energy subsidies often represent one of the most challenging political and economic issues for governments in developing countries.

There have been numerous attempts in recent years at reforming energy subsidies, but results have not been uniform across countries. In the context of MENA and sub-Saharan Africa, the Iranian and Nigerian experiments provide contrasting examples. A year after the start of the subsidy reform programme in Iran, the Nigerian government announced the elimination of fuel subsidies, hiking gasoline prices on 1 January 2012 to about $\$ 0.90 /$ litre, more than double their pre-reform level. The government's move came following the announcement that energy subsidies cost the economy an unsustainable $\$ 8$ billion in 2011, more than double the estimate for $2010 .^{24}$ However, the government's decision was met with country-wide protests and a general labour strike that threatened to disrupt the Nigerian oil sector and economy. Faced with such a backlash, the government decided to roll back the reform, reducing the new gasoline price by $30 \%$ though vowing to continue its petroleum reform efforts.

By contrast, the implementation of Iran's more comprehensive energy subsidy reform programme, which began on 19 December 2010, has been a lot smoother despite the sharper price increases it has instigated. Indeed, the reform stipulates that domestic prices for petroleum products would increase over a period of five years from as low as $\$ 0.10 /$ litre for gasoline and $\$ 0.02 /$ litre for diesel to no less than $90 \%$ of their Persian Gulf FOB prices. For natural gas, prices are to increase within 5-10 years from as low as \$0.4-0.5/MMBtu for residential and industrial users to $65 \%$ and $75 \%$ of the gas export price index respectively. ${ }^{25}$ In the first year alone, prices increased several fold, ${ }^{26}$ but little or no popular backlash was recorded, making Iran the first major oil-exporting country to reform energy subsidies substantially. What's more, official government figures show that energy consumption in the year following the introduction of price reforms fell, with demand growth in 2011 slower than in previous years.

So what lies behind the apparent success of the Iranian subsidy reform programme and what lessons can be learnt from it?

As a rule, the success of subsidy reforms hinges mainly on good timing and broad political support. The Nigerian experiment for instance suffered from lack of both, as the price increases were introduced in a context of instability following a wave of terrorist attacks and the government enjoyed limited political support at the local level and within the oil industry.

\footnotetext{
24 'Removal of gasoline subsidy in Nigeria sparks protests and cut in demand', 20 January 2012: http://www.iea.org/index info.asp?ID=2354

${ }^{25}$ Guillaume, D. et al. (2011) 'Iran: The Chronicles of the Subsidy Reform', IMF Working Paper WP/11/167, available at: http://www.imf.org/external/pubs/ft/wp/2011/wp11167.pdf; Tabatabai, H. (2010) 'The "Basic Income" Road to Reforming Iran's Subsidy System', paper prepared for presentation at the $13^{\text {th }}$ International Congress of the Basic Income Earth Network (BIEN), Universidade de São Paulo, Brazil, June 30 - July 2 , 2010, available at: http://www.sinteseeventos.com.br/bien/pt/papers/tabatabai 2010 bien2010 iran paper_v2 1008.pdf.

${ }^{26}$ From as little as $\$ 0.3 / \mathrm{MMBtu}$ to more than \$3/MMBtu for residential and commercial users.
} 
In the Iranian case, it was the opposite. The government ensured that the timing of the reform was well thought through, while the mitigation measures and public relations campaign it had designed helped broaden the support for the reform programme both at the political and grassroots levels. However, it has to be said that, over and above considerations of timing and political support, the outcome of subsidy reforms is often shaped by country-specific political, institutional, fiscal, and socio-economic circumstances. In this regard, Iran stands out from any other energy-exporting country in the MENA and sub-Saharan African regions in two main ways: first, it has by far the largest energy subsidy bill, estimated at $\$ 60-70$ billion before the introduction of the reform; and second, it is party to a longstanding diplomatic confrontation with neighbouring and Western countries over its nuclear programme which, as well as being a cause of national unity, has resulted in a range of international and unilateral sanctions being imposed mostly on its energy sector, providing further justification to the government to reform prices and reduce demand growth.

\section{Timing}

The Iranian subsidy reform legislation was approved in January 2010, but its implementation was delayed until the following December for a number of reasons. First, the government wanted to ensure price stability for most non-energy essential goods in anticipation of price increases by producers and retailers ahead of the reform. Doing so entailed a coordinated effort between the central bank and the administrative authorities, stabilising the exchange rate and building stockpiles of domestically produced and imported consumer goods to deter any speculative behaviour. Although these efforts had a limited effect on inflation, they appeared to have successfully prevented dramatic price increases and panic buying.

Secondly, the government needed to work out the modalities of implementation of the reform which were left out by the legislation. These included the magnitude of the price adjustment, especially in the first year of the programme, for different products and between various regions. This was important, considering the limit of $\$ 20$ billion imposed by the legislation on the value of savings to be generated by price increases in the first year, and the need to prevent inefficient substitution between the different fuels. And thirdly, the aim of the authorities was to start the pricing reform when energy demand is at its lowest (i.e. November-December) to minimise the impact of higher prices on the economy. ${ }^{27}$

\section{Mitigation measures}

Designing mitigation measures for price increases is arguably the lynchpin of any subsidy reform programme, not only because vulnerable consumers need to be compensated effectively for eliminating subsidies but also because such measures are crucial for obtaining broad political support for the reform. The Iranian reform legislation stipulated that $50 \%$ of the revenues generated by the price increases would be distributed to households, and after initial hesitation it was decided that the entitlement to cash handouts would be universal. The remainder of the savings would be distributed between industrial consumers $(30 \%)$, in part to support investment in energy efficiency technology, and the public sector (20\%), partly to offset the costs incurred by the reform programme. However, within the first year, the government ended up distributing up to $80 \%$ of the net proceeds to households, in an effort to maximise public support seen as necessary for the success of the reform programme, with the rest of the savings transferred to industry and agricultural users.

Furthermore, the registration process for the handouts was simplified to the extent that over $90 \%$ of households had received compensatory payments in the weeks preceding the start of

\footnotetext{
${ }^{27}$ Guillaume, D. et al. (2011) Ibid.
} 
the reform. ${ }^{28}$ Payments were made in specially-created bank accounts, and to guarantee the transparency of the entire process a widespread media campaign was orchestrated, providing daily public updates on the crediting of beneficiary accounts in addition to a dedicated website, ${ }^{29}$ which was set up by the government providing online access to the account balances for the beneficiaries. ${ }^{30}$

The size of the handouts in the first year is estimated to have been in the range of $\$ 25-40$ per person per month. For the poorer sections of the population, such compensation represented a large share of their income, lifting virtually every Iranian out of poverty. ${ }^{31}$ Coupled with the support provided to the corporate sector in the form of loan subsidies and credit assistance, the compensation measures devised as part of the reform programme helped the Iranian government obtain the necessary political support for its ambitious plans and ensure a relative degree of success, at least so far.

\section{Public relations}

An effective communication strategy forms an essential part of any subsidy reform programme, not only because it helps raise the public's awareness of the drawbacks of existing subsidies and the benefits of reform but also because public information campaigns help overcome vested interested. The Iranians mounted an extensive public relations campaign prior to the introduction of the reform, led by the president and senior government officials and mobilising business and social leaders, as well as academics. Various media outlets, public events and meetings were used to disseminate what was essentially a moral message on the part of the government, namely that subsidies are an inherently unfair and wasteful way of achieving social equity and economic development.

Parallel to the coordinated rhetoric, the authorities used a more practical method of raising public awareness by temporary inclusion in electricity bills of the true unit cost of supply, alongside the actual (low) rates being charged. This exposed consumers to new prices well before the increases, making the eventual transition less painful than it may otherwise have been. ${ }^{32}$ The government's communication strategy has been criticised for lack of consistency, clarity and transparency. ${ }^{33}$ But considering the unprecedented scale of the task undertaken by the Iranian government, their overall strategy can be said to have been relatively successful, providing lessons for both the Iranians and other governments in the region and beyond on how to design and implement a comprehensive subsidy reform programme.

\section{PART TWO: The pricing of internationally-traded gas}

\section{The pricing of internationally traded gas in MENA and sub-Saharan Africa}

As mentioned in the introduction, the combined share of MENA and sub-Saharan Africa in (mainly) global gas exports did not exceed $25 \%$ in 2010. Both regions are, on aggregate, net gas exporters, but growing domestic needs are increasingly constraining the export potential of many countries and indeed forcing some of them to turn to imports of gas to plug their deficit, particularly in MENA. However, the bulk of gas supply is sourced from within these regions, for even LNG importers Kuwait and Dubai receive part of their supplies from

\footnotetext{
${ }^{28}$ Tabatabai, H. (2010) Ibid.

${ }^{29}$ www.refahi.ir.

${ }_{30}$ Guillaume, D. et al.

${ }^{31}$ Minimum monthly wages in Iran are estimated to be around $\$ 300$.

${ }^{32}$ Guillaume, D. et al.

${ }^{33}$ Tabatabai, H.
} 
Qatar. ${ }^{34}$ Thus, at least as far as the overall MENA region is concerned, its interaction with international gas markets during the 2010s will more likely be that of a growing demand centre than a major source of new exports to international markets.

The second part of this paper chronicles the pricing mechanisms underlying gas export and import contracts, both pipeline and LNG, in both regions. Its aim is to complement the first part which focuses on domestic prices, and to help shed light on the pricing challenge facing MENA and sub-Saharan African countries as their domestic gas requirements continue to grow in years ahead.

Algeria. Algeria was the first country in MENA (and Africa) to develop a natural gas export industry, delivering its first commercial cargo of LNG to the UK in 1964. It is now the second largest exporter of gas in the region after Qatar, with annual sales in the 2000s ranging between 55 and $65 \mathrm{Bcm}$. Its nominal export capacity in 2012 stood at $78 \mathrm{Bcm} / \mathrm{yr}(53$ $\mathrm{Bcm} / \mathrm{yr}$ pipeline, $25 \mathrm{Bcm} / \mathrm{yr} \mathrm{LNG}$ ), and by 2014 this is expected to increase to $90 \mathrm{Bcm} / \mathrm{yr}$ with the commissioning of two new LNG trains. Further ahead, more export capacity could be added if the $8 \mathrm{Bcm} / \mathrm{yr}$ Galsi pipeline project becomes reality and if the existing Medgaz pipeline into Spain is expanded. In the meantime however, as in recent years, Algeria's export infrastructure will continue to run at some $70 \%$ of capacity, reflecting the lack of available feed gas owing on the one hand to stagnating/falling production and on the other to growing domestic demand of around $30 \mathrm{Bcm} / \mathrm{yr}^{35}$

The recession-induced drop in European demand in 2009 also had an impact on Algerian gas exports, as Europe absorbs some $95 \%$ of these exports (Table 5). Geographical proximity meant that Europe has always been the destination of choice for Algerian gas exports. In particular, the southern European markets of Italy, Spain and Portugal, in addition to France and Turkey, have been the main outlets for Algerian gas. Although Sonatrach is recognised to have been a reliable supplier of gas, its relations with its European customers have been subject to several disputes, notably over pricing. ${ }^{36}$

In neighbouring Tunisia and Morocco, the transit countries for the bulk of Algerian pipeline gas into Europe, Algeria is the only source of imported gas. It was not until 2011 that a sales and purchase agreement (SPA) for the delivery by Sonatrach to Morocco's public utility ONE of $0.64 \mathrm{Bcm} / \mathrm{yr}$ was concluded, following a political rapprochement between the two governments, adding to the $0.5-0.8 \mathrm{Bcm} / \mathrm{yr}$ that were being delivered from 2005 through the GME pipeline as in-kind transit royalty. Tunisia, on the other hand, has been receiving Algerian gas in lieu of transit fees since the commissioning of the Transmed pipeline in 1983, and contracted an additional $0.4 \mathrm{Bcm} / \mathrm{yr}$ from Sonatrach in 1990.

\footnotetext{
${ }^{34} 2 \mathrm{Bcm}$ out of $3.7 \mathrm{Bcm}$ in 2011, GIIGNL 2011, p.8

${ }^{35}$ For more details, see Darbouche, H. (2011) 'Algeria's Shifting Gas Export Strategy: Between Policy and Market Constraints', OIES Working Paper No. NG48, available at: http://www.oxfordenergy.org/wpcms/wpcontent/uploads/2011/03/NG48.pdf.

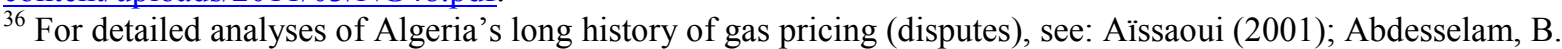
(1989) Le gaz algérien: Stratégies et Enjeux, Algiers: Bouchène; Melling, A.J. (2010) Natural Gas Pricing and Its Future: Europe as the Battleground, Washington: Carnegie Endowment for International Peace; UNDP/World Bank (2003), Cross-Border Oil and Gas Pipelines: Problems and Prospects, 89 Technical Paper 035.
} 
Table 5: Sonatrach's gas supply contracts (as at May 2012)

\begin{tabular}{|c|c|c|c|c|}
\hline Buyer & Country & $\begin{array}{l}\text { Volume } \\
\text { (Bcm/yr) }\end{array}$ & $\begin{array}{l}\text { End } \\
\text { date }\end{array}$ & Observations \\
\hline \multicolumn{5}{|l|}{$L N G$} \\
\hline GDF Suez & France & 10.2 & 2013 & $\begin{array}{l}\text { Revised in } 2007 \text { to extend the } \\
\text { contracts to } 2019 \text { and reduce the } \\
\text { volumes to around } 7.5 \mathrm{Bcm} / \mathrm{yr}\end{array}$ \\
\hline Botas & Turkey & 4 & 2014 & \\
\hline DEPA & Greece & 0.7 & 2020 & \\
\hline ENI & Italy & 1.8 & 2017 & \\
\hline Endesa & Spain & 1 & 2017 & \\
\hline CEPSA & Spain & 1.03 & 2022 & \\
\hline Iberdrola & Spain & 1.5 & 2022 & \\
\hline \multicolumn{5}{|l|}{ Pipeline } \\
\hline ENI & Italy & 19.5 & 2019 & \\
\hline ENEL & Italy & 4 & 2016 & In Salah Gas \\
\hline ENEL & Italy & 2 & 2025 & \\
\hline ENEL & Italy & 1 & 2025 & Trans-Med expansion \\
\hline Edison & Italy & 2 & 2025 & Trans-Med expansion \\
\hline $\begin{array}{l}\text { Sonatrach Gas } \\
\text { Italia }\end{array}$ & Italy & 2 & 2025 & $\begin{array}{l}\text { Trans-Med expansion. Sonatrach } \\
\text { downstream subsidiary in Italy. }\end{array}$ \\
\hline Mogest & Italy & 0.5 & 2020 & Trans-Med expansion \\
\hline World Energy & Italy & 0.45 & 2020 & Trans-Med expansion \\
\hline Bridas & Italy & 0.25 & 2020 & Trans-Med expansion \\
\hline ETAP & Tunisia & 0.4 & 2020 & \\
\hline Geoplin & Slovenia & 0.35 & 2016 & \\
\hline Gas Natural & Spain & 9 & 2020 & GME \\
\hline Transgas & Portugal & 2.5 & 2020 & GME \\
\hline ONE & Morocco & 0.64 & 2021 & GME \\
\hline $\begin{array}{l}\text { Sonatrach Gas } \\
\text { Comercializadora }\end{array}$ & Spain & 2.88 & 2029 & $\begin{array}{l}\text { Medgaz. Sonatrach downstream } \\
\text { subsidiary in Spain. }\end{array}$ \\
\hline CEPSA & Spain & 1.6 & 2029 & Medgaz \\
\hline
\end{tabular}




\begin{tabular}{|c|c|c|c|l|}
\hline Iberdrola & Spain & 1.6 & 2029 & Medgaz \\
\hline Endesa & Spain & 0.96 & 2029 & Medgaz \\
\hline GDF Suez & Spain & 0.96 & 2029 & Medgaz \\
\hline Total & & $\mathbf{7 2 . 8}$ & & LNG: 20.2; Pipeline: 52.6 \\
\hline
\end{tabular}

Source: Sonatrach, Cedigaz and GIIGNL

In all of the supply contracts listed in Table 5, prices are indexed to crude oil and/or oil products, usually using a basket of crudes or fuel, with indexation to crude being more commonly used, particularly in the LNG contracts. This has been Algeria's policy since the early 1980s - with the exception of a brief period in 2007-8 when former energy minister Chakib Khelil advocated the use of shorter term contracts and more hub-based trading of gas - and continues even in the face of the momentum building up in favour of moving away from oil-indexation in the pricing of gas in Europe. Indeed, Sonatrach was the last of the pipeline suppliers into Europe to have reportedly conceded some pricing flexibility in an agreement with its biggest customer ENI in 2011. ${ }^{37}$ Going forward, Sonatrach can be expected to be one of the main supporters of continuing oil-price linkage, but its stance will likely be affected by the decisions made by its competitors as it is no longer in the dominant supply position it once enjoyed, except perhaps in relation to Spain.

Libya. Libya is the second oldest exporter of natural gas in MENA (and Africa). Its Marsa elBrega liquefaction plant was the world's second ever LNG plant to come online in 1971 after Algeria's Camel. Its original nameplate capacity was $3.2 \mathrm{mtpa}$, but the inability of Libya's NOC to undertake any substantial upgrade under international sanctions resulted in the plant's operational capacity being limited to 0.7-1.0 mtpa for the best part of its operational life. Technically, lack of investment has also inhibited the plant's capacity to separate liquid petroleum gas (LPG) from its feed gas, meaning that it has been producing "rich" LNG which, since the early 1990s, it has only been delivering to one particular regasification train run by Spain's Gas Natural under a contract with NOC that expires in 2012. The price of LNG under this contract is believed to be indexed to the price of Brent crude.

International sanctions also constituted the main impediment to the development of new gas export projects in Libya, at least until the late 1990s when ENI and NOC began the joint development of the integrated West Libya Gas Project (WLGP), consisting of onshore and offshore gas fields (Waha and Bahr Essalem), the Mellitah processing plant, and the 10 $\mathrm{Bcm} / \mathrm{yr}$ Greenstream export line into Italy. The WLGP was commissioned in 2004 and has since been supplying Italy with $8-9 \mathrm{Bcm} / \mathrm{yr}^{38}$ and the domestic Libyan market with some 2 $\mathrm{Bcm} / \mathrm{yr}$. Exports into Italy are undertaken under three contracts that run until 2026, with prices indexed to oil products: a $4 \mathrm{Bcm} / \mathrm{yr}$ supply contract with Edison and two separate 2 $\mathrm{Bcm} / \mathrm{yr}$ contracts with GDF Suez and Energia Gas.

In the short to medium term, no new export projects are likely to be developed in Libya. Having led a revolution that resulted in the removal of a 40-year old regime, the country's new leadership will be focused on (re-)building state institutions and the economy. In the hydrocarbons sector, their aim will be to lure foreign operators back, restore and maintain pre-revolution oil production levels and devise a new development strategy and legislation. As far as gas is concerned, it is likely that the domestic market will be the main focus of the

\footnotetext{
37 'Algeria bends on contract terms', World Gas Intelligence, 22 February 2012.

${ }^{38}$ With the exception of 2011 when shipments were disrupted as a result of the uprising between February and October. Consequently, overall sales that year amounted to no more than $2 \mathrm{Bcm}$.
} 
new authorities, with any new discoveries - depending on their size - likely to be earmarked for utilisation in the power sector and industry. ${ }^{39}$ This means that Libya will remain a relatively small gas exporter to 2020, with little opportunity to expand significantly beyond existing projects.

Egypt. Egypt is the third largest exporter of gas in the MENA region after Qatar and Algeria. The nominal capacity of its export infrastructure stands at some $34 \mathrm{Bcm} / \mathrm{yr}$. It consists of two LNG plants - one at Damietta with a production capacity of $5.5 \mathrm{mtpa}$ and the other at Idku comprising two 3.6 mtpa trains; and two pipelines - the Arab Gas Pipeline (AGP), which has a nameplate capacity of $10 \mathrm{Bcm} / \mathrm{yr}$, and the $7 \mathrm{Bcm} / \mathrm{yr}$ East Mediterranean Gas (EMG) line into Israel. Between 2006 and 2009, this infrastructure was running at an average of $60 \%$ of capacity and even less so in 2010-11, with exports declining as a result of a tightening supply-demand balance.

The Damietta plant is owned by SEGAS, a joint venture between Spanish utility Unión Fenosa (40\%), ENI (40\%) and the Egyptian NOCs EGPC and EGAS (20\%). It is supplied by gas from the Egyptian grid, as opposed to the Idku plant which has dedicated offshore reserves. Train 1 (ELNG 1) at Idku is owned by BG (35.5\%), Petronas (35.5\%), EGPC and EGAS (24\%), and GDF Suez (5\%), whereas ELNG 2 has a slightly different ownership structure, with BG and Petronas owning 38\% each and EGPC/EGAS a combined 24\%. Both plants operate as tolling facilities.

While the prices agreed upon in the SPAs that were concluded between the Egyptian NOCs and the offtakers of LNG and pipeline gas in the early 2000s appeared to satisfy the interests of all parties involved given the prevailing market conditions, they became the subject of much controversy by the end of the decade following the rise in international oil prices, the decline in US gas prices and the sustained growth in gas demand on the Egyptian market. Thus, popular opinion in Egypt believed that the government was exporting gas at belowmarket prices, at a time when the country was facing severe gas (and power) shortages, which meant that opposition to the prevailing pricing policies intensified in the wake of the 2011 revolution, leading to the revision of the pricing provisions in all SPAs with the exception of the EMG contract.

Unión Fenosa is the main offtaker of LNG from Damietta, having committed under a 25-year SPA to lifting 3.2 mtpa from 2005 destined for its power plants in Spain, with the remaining capacity booked by EGAS. The initial pricing arrangement provided for the gas feedstock to be supplied by EGAS at prices aligned with the domestic market, in other words in the range of \$0.9-1.25/MMBtu plus a liquefaction fee. However, prices were revised upward in 2011.

GDF Suez lifts the entire output from ELNG 1 under a 20 -year SPA that came into effect in 2005. Prices under its contract with upstream suppliers from the West Delta Deep Marine (WDDM) concession $^{40}$ are indexed to crude oil and were initially subject to a \$4/MMBtu ceiling, which is thought to have been raised to \$6-7/MMBtu in 2011 following an agreement with the Egyptian NOCs, which also allowed greater diversion flexibility for GDF Suez. ELNG 2, on the other hand, is committed to BG Gas Marketing under a 20-year contract with prices initially wholly indexed to Henry Hub, but more recently partly indexed to NBP for the volumes initially intended to be supplied to the Brindisi receiving terminal, which was never built.

\footnotetext{
39 'Gas in the New Libya', Gas Matters, February 2012.

${ }^{40}$ These are BG (25\%), Petronas (25\%) and EGPC/EGAS (50\%).
} 
Deliveries to Jordan through the AGP began in 2003. The two parties concluded a 30 -year SPA in 2001, stipulating a take-or-pay level of $90 \%$ of the $4.2 \mathrm{Bcm}$ annual contract quantity (ACQ) for the Jordanian government and a price ceiling of \$1.5-2/MMBtu. There was a similar contract with Syria, except that the stipulated ACQ was $2.2 \mathrm{Bcm}$ and the oil-indexed gas price ceiling was close to $\$ 5 / \mathrm{MMBtu}$. Lebanon for its part was receiving Syrian gas in lieu of Egyptian gas under a 15-year swap agreement signed in 2009 by the Egyptian NOCs and the Syrian Petroleum Company. Similar to the situation with the LNG buyers, the price ceiling for AGP gas to Jordan was increased to \$6/MMBtu in 2011 despite the series of disruptions that has affected gas flows since January 2011.

The EMG contract was the most controversial, owing to the complicated nature of the relationship between Israel and its Arab neighbours, including Egypt. The SPA provided for the delivery for 15 years from 2008 of $1.7 \mathrm{Bcm} / \mathrm{yr}$ - potentially going up to $7 \mathrm{Bcm} / \mathrm{yr}$ - to $\mathrm{EMG},{ }^{41}$ which owns and operates the pipeline from El Arish in Egypt to Ashkelon in Israel, at prices indexed to crude oil, but like the other export contracts containing a ceiling believed initially to have been around \$1.25-1.5/MMBtu. Upon the start of deliveries in 2008, domestic opposition to the deal meant that the Egyptian government was forced to renegotiate prices. This subsequently resulted in a higher price $(\$ 3-3.5 / \mathrm{MMBtu})$ paid by EMG and, in turn, by the Israel Electricity Corporation (IEC), which buys the gas from EMG.

Eventually, with further price renegotiations in the wake of the revolution proving difficult and Egyptian opposition to the deal growing emboldened, the EMG contract could not be upheld and was unilaterally terminated by EGAS in 2012. The official reason given by the Egyptian NOC pointed to the non-payment by EMG of some $\$ 120$ million for the gas delivered in 2011. However, it is more likely that the decision to cancel the deal was motivated by a combination of an attempt by the Egyptian government to undercut the arbitration proceedings launched against it by EMG shareholders and IEC, and its wanting to do away with a contract that had for long been too much of a political "hot potato" - not to mention the fact that the gas supplied to Israel would now provide much-needed (though insufficient) relief for Egypt's fast-expanding, supply-short domestic market. ${ }^{42}$

For Israel, the decision might have come as no surprise and will likely have limited implications beyond the costs of the supply disruptions experienced since February $2011 .^{43}$ The government had already started executing plans to import LNG by the end of 2012, and to develop its new-found offshore gas reserves, which should begin supplying the domestic market from mid-2013. For Jordan, however, the situation is more complex, for even if new prices have been agreed with the new Egyptian authorities, the future of gas supplies through the AGP remains threatened by the political volatility in Egypt and the lack of gas supply, while plans to find new sources of gas imports will take time to materialise.

In theory, new Egyptian gas exports are still subject to a moratorium that was put in place by the government in June 2008. However, regardless of what is expressly decided about that moratorium, Egyptian gas exports will remain flat at best for the remainder of the $2010 \mathrm{~s}$. The needs of the domestic market and the outlook for supply are such that no further expansion of exports can be envisaged. In fact, the existing export commitments will continue to come under pressure because of the lack of feed gas and the likelihood that the new government will focus much of its attention on satisfying the growing domestic energy needs of

\footnotetext{
${ }^{41}$ EMG is owned by Mediterranean Gas Pipeline Ltd. (28\%), Thailand's PTT (25\%), Ampal-American Israel Corporation (12.5\%), the US investors, Samuel Sell and David Fischer (12\%), EGAS (10\%), Mehav Group (8.1\%), and Merhav Ampal Energy Holdings (4.4\%).

42 'LNG the Answer for Israel - and Jordan', World Gas Intelligence, 25 April 2012.

${ }^{43}$ The costs of the disruptions to Israel over the first year were put at \$4 billion (European Gas Daily, 16/03/12).
} 
Egyptians. Thus, the outlook for Egyptian gas exports looks bleak in the short to medium term, and the country may even have to import gas if it is to fulfil its remaining export commitments, especially if domestic supply projects from the Mediterranean offshore continue to be delayed by commercial and other challenges.

Kuwait. Kuwait was the first country in the MENA region to begin imports of LNG in 2009. Booming demand for gas in recent years has far outstripped supply, which remains mainly associated with oil. In April 2010, state-owned Kuwait Petroleum Corporation (KPC) signed a 4-year LNG supply agreement with Shell and Vitol, stipulating the purchase of up to 5 cargoes per month on a seasonal basis between April and October, to meet growing electricity demand for cooling during the summer, and reduce the burning of crude oil in its power stations, which is currently estimated at 300,000-400,000 b/d. However, since then demand for gas has continued growing rapidly and Kuwait's LNG imports reportedly increased from 11 cargoes in 2009, to 33 in 2010 and about 45 in 2011, with the import period now running from March to November. Beyond the LNG delivered under the above contract at prices indexed to Brent with a 10\% slope, Kuwait has also been buying spot cargoes from BG. In the longer term, Kuwait is likely to need permanent, year-round LNG imports, especially if its plans for the development of non-associated gas reserves, such as the Jurassic gas project, continue facing difficulties and if pipeline import options from Iraq or Qatar do not materialise.

Iran. Iran is the MENA region's (and the world's second) largest gas reserve holder, but its export ambitions have invariably been beset by chronic political, economic/commercial and technical challenges. Since the early 1960s, its exports of gas (only by pipeline) have not exceeded $10 \mathrm{Bcm} / \mathrm{yr}$. In the last 20 years, domestic gas demand has also constituted a major impediment to gas exports, doubling in size every decade to reach some $137 \mathrm{Bcm}$ in 2010 . This makes Iran the world's third largest consumer of gas after the US and Russia and one of the world's most gas intensive economies.

With demand outstripping supply and the lack of gas infrastructure between the demand centres in the northeast of the country and the southwest where domestic production is concentrated, Iran began importing gas from Turkmenistan in 1997 under a 25-year contract stipulating initially the delivery of up to $8 \mathrm{Bcm} / \mathrm{yr}$ at prices indexed to crude oil. And in 2009, both sides agreed to increase the ACQ to $14 \mathrm{Bcm}$. At around the same time, talks with Turkey for the export of Iranian gas by pipeline began, leading to the signing of a 22-year contract in 1996 for the export of up to $10 \mathrm{Bcm} / \mathrm{yr}$, which took effect in 2002 following first gas deliveries from Iran in December 2001. Turkey pays oil-indexed prices for Iranian gas, but the contract between the two parties has faced numerous setbacks because of regular supply disruptions from Iran and sabotage attacks on the pipeline by terrorists. ${ }^{44}$

Besides exports to Turkey, Iran supplies gas on a swap basis to both Azerbaijan and Armenia, delivering from 2005 up to $0.3-0.35 \mathrm{Bcm} / \mathrm{yr}$ to the former's enclave of Nakhchivan under a 25 -year contract, and agreeing to supply under a 20-year contract effective from 2009 up to $1.1-2.3 \mathrm{Bcm} / \mathrm{yr}$ to Armenia in exchange for electricity. In addition to these existing contracts, there are at least three other Iranian pipeline export projects that are different stages of development and have typically not progressed much in recent years because of commercial and pricing issues: the Iran-UAE project, intended to supply $5.2 \mathrm{Bcm} / \mathrm{yr}$ from the Salman field to the Emirate of Sharjah has stalled since 2008 because of a pricing disagreement

\footnotetext{
${ }^{44}$ For more details, see: Kinnander, E. (2010) 'The Turkish-Iranian Gas Relationship: Politically Successful, Commercially Problematic', OIES working paper No. NG38, Oxford; Adibi, S. and Fesharaki, F. (2011) 'The Iranian Gas Industry: Upstream Development and Export Potential', in: B. Fattouh and Stern, J. (Eds.), Natural Gas Markets in the Middle East and North Africa, Oxford: OIES/OUP.
} 
between the National Iranian Oil Company and Crescent Petroleum; the Iran-Pakistan pipeline is due to begin operations in 2014, with the Iranian section completed, but uncertainty on the Pakistani side prevails over both the construction of the necessary infrastructure and the ability of Pakistan to pay the agreed JCC linked price (with a 13.6\% slope) for gas (Adibi and Fesheraki, 2011); lastly, the Iran-Iraq-Syria (Islamic) gas pipeline project was floated in 2011, with no tangible contracts agreed, and is unlikely to materialise by 2020 .

Over the years, Iran has also articulated ambitious LNG export plans, amounting in total to more than 70 mtpa. However, successive rounds of international sanctions have prevented Iran from accessing the necessary technology, leaving its leaders anxious that Qatar's aggressive exploitation of the North Field, through its more successful LNG export programme, would lead to the depletion of reserves in the part of the field sitting on the Iranian side of the border (South Pars). Ultimately, Iran's undeniable gas export potential hinges on three main conditions: first, its ability to access technology through foreign investment to develop both upstream reserves and export infrastructure; second, the reform of the buy-back framework for upstream foreign investment; and thirdly, the rationalisation of domestic demand. While the last condition may be achieved (at least to some extent) through the successful implementation of the ongoing energy subsidy reform programme, the other two factors are more political and may prove more difficult to attain.

Qatar. As the world's leading LNG producer with $77 \mathrm{mtpa}$ of installed liquefaction capacity, Qatar is now the largest exporter of natural gas in the MENA region. Its initial export strategy was said to be aiming to sell a third of its volumes in Asia, a third in Europe and a third in the Americas (Table 6). However, the development of shale gas in the US, and the impact of the recession on demand in Europe, led to the diversion of large volumes to Asia-Pacific markets, even though exports to the UK were at their highest level in 2011 at almost 15 million tons (accounting for some $85 \%$ of the UK's LNG imports that year). ${ }^{45}$ This is seen as an indication of the importance for Qatar of building and maintaining strong positions in various markets, but also as a possible way of keeping Asian spot markets relatively tight in order to support its bargaining power at least while negotiating long-term, higher-netback-value supply deals. The latter consideration is particularly relevant given the apparent difficulties experienced by Qatar in recent years in concluding long-term contracts with Asian buyers that have become much less willing than before to accept its demand for near crude oil parity, given that the potential alternative sources of supply available to them are increasing (Australia, North America, and East Africa). But with LNG demand in Asia set to grow and the need for Qatar to place its flexible volumes in premium markets before the coming online of a new wave of LNG supply towards the end of this decade, it is expected that sellers Qatargas and RasGas will show greater price flexibility.

Regionally, Qatar is also a significant supplier of pipeline gas, exporting from 2007 some 20 $\mathrm{Bcm} / \mathrm{yr}$ to the UAE and Oman through the Dolphin line. This is done under long-term (25year) agreements with heavily discounted prices $(\$ 1.3-1.5 / \mathrm{MMBtu})$ resulting from the political importance accorded to the project in its early days. However, the expansion of the Dolphin pipeline to its design capacity of $33 \mathrm{Bcm} / \mathrm{yr}$ and, concomitantly, of supplies from Qatar has so far stalled mainly because of disagreement over prices and the moratorium imposed by Doha until 2014-15 on North-Field-based new gas export projects. In the meantime, and even beyond 2015, Qatar is likely to shift its focus to the domestic market for future gas monetisation, with any future regional gas export projects unlikely to be based on prices other than those reflecting prevailing market conditions.

\footnotetext{
45 'Qatar ups UK sales as sabres rattle’, World Gas Intelligence, 11 January 2012.
} 
Table 6: Qatar's LNG supply contracts (as at May 2012)

\begin{tabular}{|c|c|c|c|c|}
\hline Seller & Buyer (country) & Volume (mtpa) & End date & $\begin{array}{c}\text { Indexation } \\
\text { (Observations) }\end{array}$ \\
\hline RasGas II & $\begin{array}{l}\text { Distrigas } \\
\text { (Belgium) }\end{array}$ & 2.05 & 2027 & Zeebrugge Hub \\
\hline RasGas II & $\begin{array}{l}\text { EDF Trading } \\
\text { (Belgium) }\end{array}$ & 3.4 & 2012 & Zeebrugge Hub \\
\hline Qatargas III & CNOOC (China) & 2 & 2034 & $\mathrm{JCC}$ \\
\hline Qatargas IV & $\begin{array}{l}\text { PetroChina } \\
\text { (China) }\end{array}$ & 3 & 2031 & $\mathrm{JCC}$ \\
\hline Qatargas IV & Shell (Dubai) & 0.7 & 2021 & Brent \\
\hline Qatargas II & Total (France) & 1.85 & 2033 & Brent \\
\hline RasGas II & Edison Gas (Italy) & 4.6 & 2033 & Oil products \\
\hline RasGas II & Petronet (India) & 5 & 2029 & JCC \\
\hline Qatargas I & $\begin{array}{c}\text { Chubu Electric } \\
\text { (Japan) }\end{array}$ & 4 & 2021 & $\mathrm{JCC}$ \\
\hline Qatargas I & $\begin{array}{c}\text { Japanese } \\
\text { Consortium } \\
\text { (Japan) }\end{array}$ & 2 & 2021 & $\mathrm{JCC}$ \\
\hline Qatargas I & $\begin{array}{c}\text { Chubu Electric } \\
\text { and Shizuoka Gas } \\
\text { (Japan) }\end{array}$ & 0.2 & 2021 & $\begin{array}{l}\text { JCC (effective } \\
\text { from 2016) }\end{array}$ \\
\hline RasGas I & Kogas (Korea) & 4.9 & 2024 & $\mathrm{JCC}$ \\
\hline RasGas III & Kogas (Korea) & 2.1 & 2026 & $\mathrm{JCC}$ \\
\hline RasGas III & Kogas (Korea) & 2 & 2033 & $\begin{array}{l}\text { JCC (effective } \\
\text { from 2013) }\end{array}$ \\
\hline Qatargas II & Total (Mexico) & 0.7 & 2033 & $\mathrm{HH}$ \\
\hline Qatargas I & $\begin{array}{c}\text { Gas Natural } \\
\text { (Spain) }\end{array}$ & 1.4 & 2012 & Brent \\
\hline Qatargas I & $\begin{array}{c}\text { Gas Natural } \\
\text { (Spain) }\end{array}$ & 1.5 & 2025 & Brent \\
\hline Qatargas III & PGNiG (Poland) & 1 & 2034 & $\begin{array}{l}\text { Brent (effective } \\
\text { from 2014) }\end{array}$ \\
\hline RasGas II & Endesa (Spain) & 0.8 & 2025 & Brent \\
\hline RasGas III & CPC (Taiwan) & 3 & 2032 & JCC \\
\hline
\end{tabular}




\begin{tabular}{|c|c|c|c|c|}
\hline RasGas III & CPC (Taiwan) & 1.5 & 2033 & $\begin{array}{c}\text { JCC (effective } \\
\text { from 2013) }\end{array}$ \\
\hline Qatargas IV & Centrica (UK) & 2.4 & 2014 & NBP \\
\hline Qatargas II & $\begin{array}{c}\text { QP and } \\
\text { ExxonMobil (UK) }\end{array}$ & 9.2 & 2033 & NBP \\
\hline Qatargas II & Total (UK) & 1.5 & 2033 & NBP \\
\hline Qatargas II & Total (US) & 1.15 & 2033 & HH \\
\hline RasGas III & $\begin{array}{c}\text { QP and } \\
\text { ExxonMobil (US) }\end{array}$ & 8 & 2034 & HH \\
\hline Qatargas III & $\begin{array}{c}\text { QP and } \\
\text { ConocoPhillips } \\
\text { (US) }\end{array}$ & 3.8 & 2034 & HH \\
\hline Qatargas IV & QP and Shell (US) & 3.3 & 2035 & \\
\hline Total & & $\mathbf{7 7 . 0 5}$ & & \\
\hline
\end{tabular}

Source: GIIGNL, Cedigaz, and Andy Flower

Note: Most of the Henry Hub indexed volumes are being diverted to other markets in Europe and Asia.

Abu Dhabi. Abu Dhabi became the first exporter of LNG in the Middle East when its ADGAS plant began operations in 1977. ADGAS has a $5.6 \mathrm{mtpa}$ nameplate production capacity and is $70 \%$ owned by the Abu Dhabi National Oil Company (ADNOC), $15 \%$ by Mitsui, $10 \%$ by BP and $5 \%$ by Total. After the expansion of the plant to its current capacity in 1994, ADGAS began supplying Japan's TEPCO under a 25-year agreement which stipulates the delivery of an average of $4.9 \mathrm{mtpa}$. Prices under this contract are indexed to the JCC crude oil price through a formula that includes an S-curve but, having failed to agree on a new formula since 2004 , ADGAS and TEPCO remain without an agreed price. ${ }^{46}$

ADGAS has yet to announce its plans beyond the expiration of its contract with TEPCO in 2019 , but it is widely believed that it will at least scale down exports because of the acute gas shortage the emirate faces owing to rapidly increasing domestic demand. Indeed, besides importing 8-9 Bcm/yr of pipeline gas from Qatar, Abu Dhabi is now considering additional imports of LNG to meet its growing gas deficit, following in the footsteps of Dubai which began importing LNG in 2011 at prices indexed to Brent with a 15\% slope via a contract with Shell. Abu Dhabi's LNG import plans will undoubtedly firm up if its domestic supply options, notably the Shah sour gas and the Integrated Gas Development projects, continue to be delayed in the face of commercial and technical challenges. ${ }^{47}$

Oman. Exports of LNG from Oman began in 2000 with the start-up of the two-train Oman LNG (OLNG) plant which has a nameplate capacity of $7.4 \mathrm{mtpa}$ and is owned $51 \%$ by the Omani government, $30 \%$ by Shell, $5.54 \%$ by Total, $5 \%$ by a Korean consortium (Kogas, Samsung, Daewoo, Hyundai, SK Corporation), 2.77\% by Mitsubishi, $2.77 \%$ by Mitsui, 2\% by Partex, and $0.92 \%$ by Itochu. Currently, OLNG has three supply contracts: a $4.06 \mathrm{mtpa}$

\footnotetext{
${ }^{46}$ Flower, A. (2011) 'The UAE Gas Sector: Challenges and Solutions for the Twenty-First Century', in: B. Fattouh and J. Stern (Eds.).

${ }^{47}$ Initial plans, promoted by state-owned investment firms Mubadala and IPIC, aim at developing in the first phase $4 \mathrm{mtpa}$ of floating regasification capacity, with the option to expand it to 8-9 mtpa at a later stage.
} 
(5.55 Bcm/yr) contract with Korea's Kogas that runs until 2024 and two $0.73 \mathrm{mtpa}$ (1 $\mathrm{Bcm} / \mathrm{yr}$ ) agreements with Osaka Gas and Itochu of Japan running until 2026. In the Japanese contracts, the price of LNG is indexed to the JCC crude price with an S-curve, but the Kogas contract does not contain an S-curve.

Qalhat LNG (QLNG) is a more recent project with a single $3.7 \mathrm{mtpa}$ train that began operating in 2006. It is owned by the government of Oman (46.84\%), OLNG (36.8\%), Union Fenosa Gas (7.36\%), Itochu (3\%), Mitsui (3\%), and Mitsubishi (3\%). Most of its volumes are contracted to Mitsubishi (0.8 mtpa) until 2020, Osaka Gas (0.8 mtpa) until 2026, and Union Gas Fenosa (1.65 mtpa) until 2025. The prices in the contract with Osaka Gas are indexed to JCC through an S-curve formula but not in the deal with Mitsubishi where indexation is to Henry Hub, while the indexation in the agreement with Union Gas Fenosa is on Brent crude with profit-sharing provisions for cargoes diverted to higher-paying markets in Asia.

Oman's LNG plants have been running at about $80 \%$ of capacity in recent years because of lack of feedstock. Like other countries in the MENA region, with demand for gas outpacing supply, Oman finds itself in a position of constrained exports. Efforts aimed at developing costly, more challenging gas resources are underway, but unfavourable commercial terms caused mainly by artificially-low domestic prices remain a major impediment. In the years to 2020, it is unlikely that Oman's LNG exports will increase. In fact, depending on how current domestic supply projects fare, the Sultanate may require additional imports of gas to meet its domestic requirements.

Yemen. Yemen is the latest country in the Middle East to join the ranks of LNG exporters. In 2009, it loaded its first cargo of LNG from the $6.7 \mathrm{mtpa}$ Yemen LNG (YLNG) plant owned (and led) by Total (39.62\%), Hunt (17.22\%), Yemen Gas Company (16.73\%), SK Corporation (9.55\%), Kogas (6\%), Hyundai Corporation (5.88\%), GASSP (5\%). It has three 20 -year supply contracts with GDF Suez for $2.55 \mathrm{mtpa}$, Total for $2 \mathrm{mtpa}$, and Kogas for 2 mtpa. The volumes in the first two contracts were originally earmarked for the US market and thus their prices are indexed to Henry Hub, while in the contract with Kogas prices are indexed to JCC. However, most of the volumes sold to GDF Suez and Total are diverted to higher-value markets in Asia and the profits generated are shared between YLNG and the offtakers.

Nigeria. At 5.3 Tcm, Nigeria's proven natural gas reserves are the largest in Africa. Yet, it was not until relatively recently that Nigeria began marketing its gas resources through LNG exports from the Bonny Island liquefaction facility that was started up in 1999. With the commissioning of its sixth train in 2008 , the plant's nominal capacity topped $22 \mathrm{mtpa}$. With such a large resource base and some $15 \mathrm{Bcm}$ of gas still flared every year, it comes as no surprise that Nigeria has ambitious plans for its gas sector, planning further expansion of commercial production, not only to increase export capacity, but also to fuel a much-needed domestic power generation expansion programme. However, most of these plans are either stalled or progressing at a slow pace, suffering from a combination of changing Atlantic Basin market conditions and unstable Nigerian politics.

The Bonny Island plant is owned and operated by Nigeria LNG (NLNG), comprising the NNPC (49\%), Shell (25.6\%), Total (15\%), and ENI (10.4\%). Its contracted sales into Europe, amounting to approximately $12 \mathrm{mtpa}$, are sold at prices indexed to (mostly Brent) crude prices, while the volumes initially targeted at the US and Mexico with prices indexed to Henry Hub have, since the collapse of US prices in 2008, mostly been diverted, in some cases under term, oil-indexed contracts, to premium markets in Asia in particular. In the latter part of the 2000s, NLNG was planning to add two $8.5 \mathrm{mtpa}$ trains, potentially taking its total capacity to over $39 \mathrm{mtpa}$. By the time its train 6 was commissioned, NLNG had succeeded in 
concluding sales and purchase agreements with BG, Shell, Total, ENI, and Occidental for almost the entire capacity of train 7 , which has yet to receive a final investment decision. All of those volumes were earmarked for North American terminals (Table 7).

Table 7: Nigeria's LNG supply contracts (as at May 2012)

\begin{tabular}{|c|c|c|c|c|}
\hline Buyer & Country & Volume & End date & $\begin{array}{c}\text { Indexation } \\
\text { (observations) }\end{array}$ \\
\hline GDF Suez & France & 0.33 & 2022 & Brent \\
\hline ENEL & France & 2.5 & 2022 & Brent \\
\hline Transgas & Portugal & 1 & 2022 & Brent \\
\hline Transgas & Portugal & 1.46 & 2026 & Brent \\
\hline Gas Natural & Spain & 1.2 & 2022 & Brent \\
\hline Gas Natural & Spain & 2 & 2025 & Brent \\
\hline Endesa & Spain & 0.75 & 2025 & Brent \\
\hline Iberdrola & Spain & 0.38 & 2025 & Brent \\
\hline ENI & Spain & 1.1 & 2028 & Brent \\
\hline Botas & Turkey & 0.9 & 2022 & Brent \\
\hline Total & US & 1.1 & 2027 & $\begin{array}{c}\text { HH (PSM for } \\
\text { diverted volumes) }\end{array}$ \\
\hline Shell & US/Mexico & 1.4 & 2027 & $\begin{array}{c}\text { HH (PSM for } \\
\text { diverted volumes) }\end{array}$ \\
\hline Shell & US/Mexico & 1.1 & 2025 & $\begin{array}{c}\text { HH (PSM for } \\
\text { diverted volumes) }\end{array}$ \\
\hline $\mathrm{BG}$ & US & 2.3 & 2032 & $\begin{array}{c}\text { HH (volumes from } \\
\text { planned NLNG } \\
\text { Train 7) }\end{array}$ \\
\hline Shell & US & 2 & 2032 & $\begin{array}{c}\mathrm{HH} \text { (volumes from } \\
\text { planned NLNG } \\
\text { Train 7) }\end{array}$ \\
\hline Total & US & 1.4 & 2032 & $\begin{array}{c}\mathrm{HH} \text { (volumes from } \\
\text { planned NLNG } \\
\text { Train 7) }\end{array}$ \\
\hline ENI & US & 1.4 & 2032 & $\begin{array}{c}\text { HH (volumes from } \\
\text { planned NLNG } \\
\text { Train 7) }\end{array}$ \\
\hline Occidental & US & 1 & 2032 & $\begin{array}{c}\text { HH (volumes from } \\
\text { planned NLNG } \\
\text { Train 7) }\end{array}$ \\
\hline Total & & 23.3 & & \\
\hline
\end{tabular}

Source: GIIGNL, Cedigaz and Energy Intelligence 
Other LNG projects under consideration in Nigeria include Brass LNG and Olokola LNG (OKLNG), with companies in charge of their development being formed in the first half of the last decade. Brass LNG is owned by NNPC (49\%), ConocoPhillips, ENI and Total (17\% each) and consists of two $5 \mathrm{mtpa}$ trains, while OKLNG is a four-5.5 mtpa-train joint venture between NNPC (46.75\%), Shell (19.5\%), Chevron (19.5\%), and BG (14.25\%) based upon equity lifting by the IOC partners. NNPC has now reduced its equity stake to $40 \%$ in favour of LNG Japan, a joint-venture between Sumitomo and Sojitz. Both projects are still awaiting a final investment decision which hinges principally on the issue of feed gas availability, and more generally on the future investment climate in Nigeria and whether/how the PIB will be implemented.

In addition to LNG exports, Nigeria has long aspired to become a regional pipeline supplier to neighbouring countries in West (and North) Africa. ${ }^{48}$ The West Africa Gas Pipeline (WAGP), which was completed in 2008, allows it to export gas to Benin, Togo, and Ghana, with an envisaged extension into the Ivory Coast at a later stage. WAGP is owned by Chevron (36.9\%), NNPC (24.9\%), Shell (17.9\%), Takoradi Power Company (16.3\%), Société Togolaise de Gaz (2\%), and Société BenGaz (2\%). It has an initial transport capacity of about $2 \mathrm{Bcm} / \mathrm{yr}$ that can in future be expanded to 3-4 $\mathrm{Bcm} / \mathrm{yr}$ with additional compression. Currently, gas is being delivered on long term contracts to Ghana's utility VRA and to Togo, stipulating for Ghana an ACQ of $132 \mathrm{mmscf} / \mathrm{d}$ and the indexation of prices to crude oil. Integrated into the delivery price of gas is an estimated transportation tariff of \$3.80/MMBtu for WAGP and a reported \$1.2/MMBtu for the Escravos-Lagos Pipeline. So far, WAGP has been running at below capacity, owing mostly to the lack of available gas supply in Nigeria. As the situation is unlikely to improve in the foreseeable future, with deliveries from Nigeria being unreliable, Ghana is considering alternative supply options, including from its own offshore associated gas reserves (Jubilee).

Equatorial Guinea. Equatorial Guinea was the second country in West Africa to become an exporter of LNG after Nigeria. Its single $3.4 \mathrm{mtpa}$ train was started up in 2007 and is operated by Marathon, which owns $60 \%$ of the plant, with the national company GN Sonagas having $25 \%$, Mistui $8.5 \%$, and Marubeni $6.5 \%$. All of the output of the plant is sold to BG on flexible terms under a 17-year SPA, with volumes initially earmarked for the US being placed in a variety of markets - mainly in Asia under term, oil-indexed contracts - and the upside generated shared between BG and EGLNG. Plans for a second LNG train have yet to materialise, but recent discoveries of gas offshore Bioko Island could pave the way for the expansion of EGLNG's production capacity.

Angola. The Angola LNG project consists of a 5.2 mtpa plant owned by Chevron (36.4\%), Sonangol (22.8\%), and ENI, BP and Total each with $13.6 \%$. It uses previously-flared associated gas as well as non-associated offshore gas from newly-discovered fields. The plant's first cargo I expected to be loaded in July 2012, and the plan is for the bulk of the plant's volumes to be marketed on a flexible basis by a dedicated company owned by Sonangol (50\%), Chevron (23.6\%), and ENI, BP and Total with 8.8\% each. However, the Angola LNG consortium will remain responsible for any sales to the initial target market, the US.

\footnotetext{
${ }^{48}$ The 30 Bcm/yr, 4000-km Trans-Saharan Gas Pipeline linking Nigeria to Algeria through Niger received much publicity in the 2000s but has never come remotely close to becoming a reality. It remains a far-fetched project not only because of the technical and commercial challenges it faces but also because of the lack of available feedstock in Nigeria. Thus, this is a project that is far from likely to materialise before 2020, if ever.
} 


\section{Conclusions}

Domestic pricing policies in gas-rich countries in MENA and sub-Saharan Africa originate in a shared political economy rationale, pertaining to the nature of gas as a hydrocarbon resource and the rent it generates for these developing economies. However, from a gas market perspective, what sets both regions apart are the facts that: a) MENA gas markets are a lot more developed and mature than in sub-Saharan Africa, owing to the wider distribution of reserves between countries and the general prevalence of relative political and institutional stability; b) MENA governments generally have greater control over gas value chains, which tends not to be the case in sub-Saharan Africa where IOCs play a bigger role in the production, processing and export of gas; and c) governments in MENA countries have more financial resources available to them. These factors mean that the effects of artificially-low prices on gas development and the extent to which they are being addressed vary between both regions.

Overall, artificially-low domestic gas prices are no longer sustainable in the majority of countries in MENA and sub-Saharan Africa. Besides causing distorted consumption patterns, they have hampered the development of new gas supply which, in some cases, has choked off sustainable investment and growth in strategic sectors such as power and industry, with serious consequences for long-term economic development. Furthermore, the framework of logic in which existing domestic pricing practices are embedded has run its course and tends to be out of step with reality, with new gas production coming increasingly from nonassociated, more costly reserves.

Thus, there is growing recognition among policymakers of the need to rethink gas pricing policies with a view to introducing (higher) prices that are at least reflective of the cost of supply in the short term. Already, countries like Iran, Egypt, Bahrain, Oman and Nigeria have made varying attempts at reforming domestic gas prices, but more broadly any change in pricing policies will ultimately depend on country-specific political, economic, resourceendowment, fiscal and financial circumstances. What's more, the success (or failure) of pricing reform experiments in countries such as Iran and Nigeria should provide useful lessons for the other countries.

So far, instead of raising gas prices and encouraging the development of domestic gas supplies, cash- and oil-rich GCC countries have chosen to burn crude oil for power generation and/or import LNG at international prices to plug their growing gas deficits. Other countries in sub-Saharan Africa, such as the Ivory Coast and Ghana, have turned to gas both domestic and imported - as an alternative to oil products, given that, even at international prices, gas remains cheaper on an energy content basis than the available alternatives.

Although in the majority of the countries under consideration, ongoing and anticipated gas pricing reforms are unlikely to lead to a full liberalisation of prices by 2020 (i.e. where gas prices will be determined by gas-on-gas competition or, more probably, by some form of export net-back price), they will constitute an important step towards addressing the emerging gas crisis in these regions. As far as the MENA region is concerned, even with these pricing reforms, it is almost certain that, overall, its interaction with international gas markets is more likely to be as a growing demand (and import) centre than as a major source of new supply. Additional exports from the region would come mainly from Qatar and to a lesser extent Algeria, would most certainly be in the form of LNG, and would not come into the market until the second half of the 2010s. Countries that will need to import gas to satisfy their needs will do so at international prices - likely to be indexed to oil - and this will only provide further incentive for governments to reform domestic prices. Logically, this should 
also encourage further development of regional gas trade, but where prices will not be the obstacle, issues of politics and gas supply availability are likely to continue undermining such a prospect in coming years.

In sub-Saharan Africa, the requirement for infrastructure investment to facilitate greater domestic consumption presents a challenge for growth in domestic gas consumption, though recent discoveries of large reserves offshore East Africa are likely to change the prospects for local and regional gas use. Tanzania and Mozambique will almost certainly begin exporting gas from the newly-discovered deposits by the end of the 2010s, starting with LNG then possibly by pipeline into neighbouring countries. If regional gas trade proves difficult, then both countries could help develop the sub-regional power pools that have thus far struggled to take off. In existing markets, mainly in West Africa, the focus is more likely to be on domestic market development, particularly in Nigeria, though additional exports of LNG could be developed by the end of the current decade in other West African countries (Equatorial Guinea, Cameroon, and Angola). 


\section{References}

Abdesselam, B. (1989) Le gaz algérien: Stratégies et Enjeux, Algiers: Bouchène.

Adibi, S. and Fesharaki, F. (2011) 'The Iranian Gas Industry: Upstream Development and Export Potential', in: B. Fattouh and Stern, J. (Eds.), Natural Gas Markets in the Middle East and North Africa, Oxford: OIES/OUP.

African Energy (2010), 'Libya’s Energy Future', London: Cross-border Information.

Aïssaoui, A. (2001) Algeria: The Political Economy of Oil and Gas', Oxford: OIES/OUP.

Aïssaoui, A. (forthcoming - 2012) 'Saudi Arabia's Economic Diversification: Progress in the Context of the GCC and Challenges', in: Luciani, G. (ed.) Resource Blessed: Diversification and the Gulf Development Model, Berlin: Gerlach.

Bressand, F. et al. (2007) 'Curbing Global Energy Demand Growth: The Energy Productivity Opportunity', McKinsey Global Institute.

Coady, D. et al. (2010) 'Petroleum Product Subsidies: Costly, Inequitable, and Rising', IMF Staff Position Note, Washington.

Darbouche, H. (2011) 'Algeria's Shifting Gas Export Strategy: Between Policy and Market Constraints', OIES Working Paper No. NG48, Oxford

Darbouche, H. and Fattouh, B. (2011) 'The Implications of the Arab Uprisings for Oil and Gas Markets', OIES Working Paper No. MEP2, Oxford.

Economist Intelligence Unit (2010) ‘The GCC in 2020: Broadening the Economy', London.

Farina, M.F. (2011) 'Flare Gas Reduction: Recent Global Trends and Policy Considerations', GE Energy, GEA18592 (10/2010).

Fattouh, B. (2011) 'The Saudi Gas Sector and its Role in Industrialisation: Developments, Challenges and Options', B. Fattouh and J. Stern (Eds.).

Favreau, D. (2010) 'A Review of Natural Gas Markets: South Africa', Cedigaz Insights No. 8 , Paris.

Flower, A. (2011) 'The UAE Gas Sector: Challenges and Solutions for the Twenty-First Century', in: B. Fattouh and J. Stern (Eds.).

Guillaume, D. et al. (2011) 'Iran: The Chronicles of the Subsidy Reform', IMF Working Paper WP/11/167, Washington.

Hang, L. and Tu, M. (2007) 'The Impacts of Energy Prices on Energy Intensity: Evidence from China', Energy Policy, 35 (5), pp. 2978-2988.

IGU (2012), 'Wholesale Gas Price Formation', PGCB Study Group 2, World Gas Conference 2012, Kuala Lumpur. 
IEA/OPEC/OECD/World Bank (2010), 'Analysis of the scope of energy subsidies and suggestions for the G-20 Initiative', 16 June.

Julius, D. and Mashayekhi, A. (1990) The Economics of Natural Gas: Pricing, Planning and Policy', Oxford: OIES/OUP.

Kinnander, E. (2010) 'The Turkish-Iranian Gas Relationship: Politically Successful, Commercially Problematic', OIES working paper No. NG38, Oxford.

Legros, G. et al. (2009) 'The Energy Access Situation in Developing Countries: A Review Focusing on the Least Developed Countries and sub-Saharan Africa', WHO/UNDP.

Luciani, G. (forthcoming - 2012) 'Domestic pricing of energy and industrial competitiveness', in: Luciani, G. (ed.) Resource Blessed.

Melling, A.J. (2010) Natural Gas Pricing and Its Future: Europe as the Battleground, Washington: Carnegie Endowment for International Peace.

Onyeukwu, H. (2009) 'Nigerian Gas Master Plan and Policy: Is it a Constrained Energy Policy?’ Unpublished paper.

Razavi, H. (2009) 'Natural Gas Pricing in Countries of the Middle East and North Africa', The Energy Journal, 30 (3), pp. 1-22.

Salehi-Isfahani, D. (2010) 'Will Iran's Poor Lose from Subsidy Reform?' http://djavad.wordpress.com/2010/03/15/will-irans-poor-lose-from-the-subsidy-reform.

Tabatabai, H. (2010) 'The “Basic Income” Road to Reforming Iran's Subsidy System', paper prepared for presentation at the $13^{\text {th }}$ International Congress of the Basic Income Earth Network (BIEN), Universidade de São Paulo, Brazil, June 30 - July 2, 2010.

UNDP/World Bank (2003), Cross-Border Oil and Gas Pipelines: Problems and Prospects, 89 Technical Paper 035, Washington.

UNEP (2002), 'Reforming Energy Subsidies: Opportunities to Contribute to the Climate Change Agenda', Washington.

Victor, D. (2009) 'The Politics of Fossil Fuel Subsidies', Global Subsidies Initiative, Geneva.

World Bank (2009) 'Africa Energy Poverty', paper prepared for the G8 Energy Ministers Meetings, Rome 24-25 May 2009.

World Bank (2010) 'Subsidies in the Energy Sector: An Overview', Background paper for the World Bank Group energy sector strategy, Washington.

World Energy Council (2001), 'Pricing Energy in Developing Countries', London. 